\title{
Evaluation of a
}

County Enforcement

Program With

A Primary Seat

Belt Ordinance:

ST. LOUIS COUNTY,

MISSOURI 
This publication is distributed by the U.S. Department of Transportation, National Highway Traffic Safety Administration, in the interest of information exchange. The opinions, findings and conclusions expressed in this publication are those of the author(s) and not necessarily those of the Department of Transportation or the National Highway Traffic Safety Administration. The United States Government assumes no liability for its content or use thereof. If trade or manufacturers' names or products are mentioned, it is because they are considered essential to the object of the publication and should not be construed as an endorsement. The United States Government does not endorse products or manufacturers. 
Technical Report Documentation Page

\begin{tabular}{|c|c|c|c|c|}
\hline $\begin{array}{l}\text { 1. Report No. } \\
\text { DOT HS } 811292\end{array}$ & \multicolumn{2}{|l|}{ 2. Government Accession No. } & \multicolumn{2}{|c|}{ 3. Recipient's Catalog No. } \\
\hline \multicolumn{3}{|l|}{ 4. Title and Subtitle } & \multicolumn{2}{|l|}{ 5. Report Date } \\
\hline \multirow{2}{*}{\multicolumn{3}{|c|}{$\begin{array}{l}\text { Evaluation of a County Enforcement Program With a Primary Seat } \\
\text { Belt Ordinance: St. Louis County, Missouri }\end{array}$}} & \multicolumn{2}{|l|}{ May 2010} \\
\hline & & & \multicolumn{2}{|c|}{ 6. Performing Organization Code } \\
\hline 7. Authors & \multicolumn{2}{|c|}{ J. L. Nichols, M. G Solomon, R. H. B. Chaffe, and D. F. Preusser } & \multicolumn{2}{|c|}{ 8. Performing Organization Report No. } \\
\hline \multirow{2}{*}{\multicolumn{3}{|c|}{$\begin{array}{l}\text { 9. Performing Organization Name and Address } \\
\text { Preusser Research Group, Inc. } \\
7100 \text { Main Street } \\
\text { Trumbull, CT } 06611\end{array}$}} & \multicolumn{2}{|c|}{ 10. Work Unit No. (TRAIS) } \\
\hline & & & \multicolumn{2}{|c|}{$\begin{array}{l}\text { 11. Contract or Grant No. } \\
\text { DTNH22-05-D-15043 }\end{array}$} \\
\hline \multirow{3}{*}{\multicolumn{3}{|c|}{$\begin{array}{l}\text { 12. Sponsoring Agency Name and Address } \\
\text { National Highway Traffic Safety Administration } \\
\text { Office of Behavioral Safety Research } \\
1200 \text { New Jersey Avenue SE. } \\
\text { NVS-431 } \\
\text { Washington, DC } 20590\end{array}$}} & \\
\hline & & & \multicolumn{2}{|c|}{ Final Report } \\
\hline & & & \multicolumn{2}{|c|}{ 14. Sponsoring Agency Code } \\
\hline \multicolumn{5}{|l|}{ 15. Supplementary Notes } \\
\hline \multicolumn{5}{|c|}{$\begin{array}{l}\text { 16. Abstract } \\
\text { In March 2007, St. Louis County implemented a seat belt ordinance that allowed for traditional } \\
\text { enforcement procedures. In order to increase usage on St. Louis County roads, particularly on roadways } \\
\text { with fatal or disabling injury crashes, the St. Louis County Police Department conducted an intense high } \\
\text { visibility enforcement (HVE) campaign along an } 8 \text {-mile corridor on State Highway } 21 \text { in the southeastern } \\
\text { part of the county. This corridor was selected in part because there had been at least } 8 \text { fatal or disabling } \\
\text { injury crashes along this roadway in recent years. This campaign was characterized by a strong } \\
\text { enforcement effort that was accompanied by only modest publicity in the form of roadway signage. } \\
\text { Saturation patrols and enforcement zones resulted in about } 1,000 \text { citations issued over a two-week } \\
\text { period. The results showed significant increases in all awareness indices and a } 4.9 \text { percentage point } \\
\text { increase in belt use compared to the control corridor. Belt use increased as much among occupants of } \\
\text { pickup trucks as passenger cars and increased the most for passengers, reaching nearly } 90 \% \text {. These } \\
\text { data suggest that enactment and enforcement of a statewide primary enforcement law would likely result } \\
\text { in a significant increase in statewide seat belt usage. If Missouri enacted a statewide primary law } \\
\text { upgrade and implemented regular HVE programs, similar to the program implemented in St. Louis } \\
\text { County, Missouri would save an estimated } 30 \text { to } 70 \text { lives, prevent } 400 \text { to } 900 \text { serious injuries, and save } \\
\$ 110 \text { million to } \$ 215 \text { million in lower economic costs annually. }\end{array}$} \\
\hline \multicolumn{2}{|l|}{$\begin{array}{l}\text { 17. Key Words } \\
\text { Seat Belt Use } \\
\text { Primary Enforcement } \\
\text { High Visibility Enforcement }\end{array}$} & \multicolumn{3}{|c|}{$\begin{array}{l}\text { Document is available to the public from the } \\
\text { National Technical Information Service } \\
\text { www.nhtsa.dot.gov. }\end{array}$} \\
\hline $\begin{array}{r}\text { 19. Security Classif.(of this report) } \\
\text { Unclassified }\end{array}$ & $\begin{array}{r}\text { 20. Security Classif.(of this page) } \\
\text { Unclassified }\end{array}$ & & $\begin{array}{r}\text { 21. No. of Pages } \\
53\end{array}$ & 22. Price \\
\hline
\end{tabular}




\section{Table of Contents}

Page

Technical Summary

V

\section{Background}

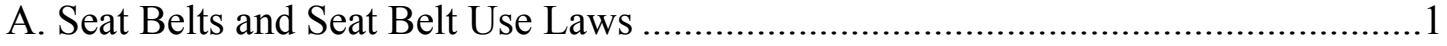

B. Relative Effectiveness of Primary and Secondary Laws ......................................

C. Missouri's SBU Law and Changes in Seat Belt Usage............................................2

D. A Primary Seat Enforcement Ordinance in St. Louis County ................................

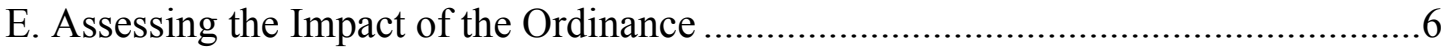

\section{The Program}

A. The Corridor Program Approach ...........................................................................

B. Selection of a Target Corridor...............................................................................

C. Historical Use Rates on the Target Corridor ......................................................

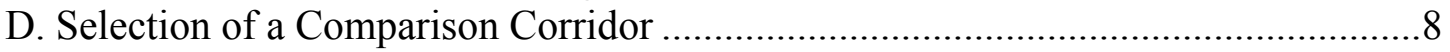

E. Development of the St. Louis County HVE Program ........................................ 9

\section{Methodology and Results}
A. Activity Levels

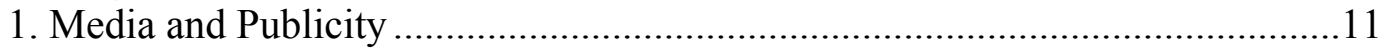

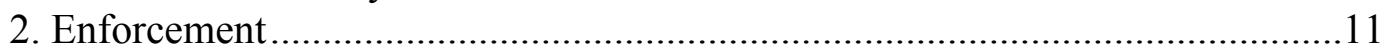

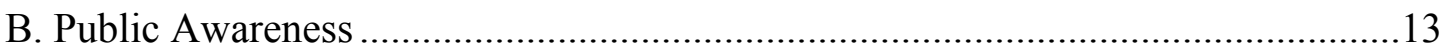

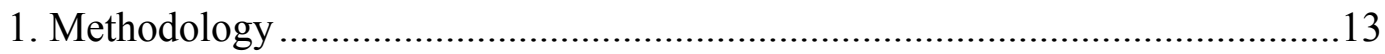

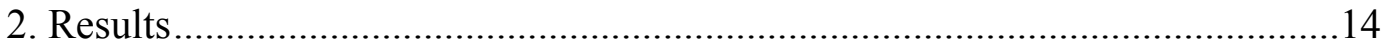

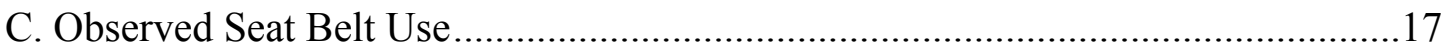

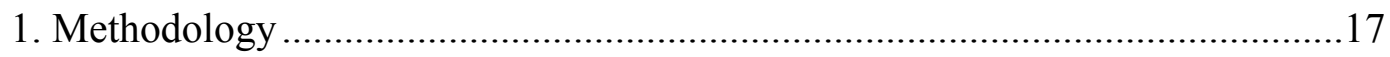

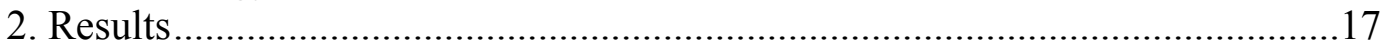

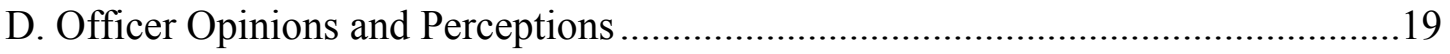

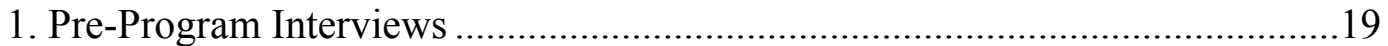
2. Post-Program Officer Surveys .................................................................20
3. Comments From the Activity Form ............................................................21
E. Potential Impact of a Statewide Primary Law .....................................................22

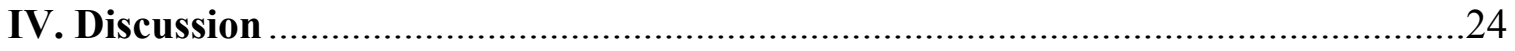

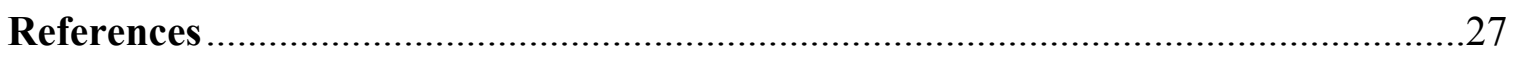

\section{Appendices}

Appendix A. Activity Reporting Form - (Completed) .......................................

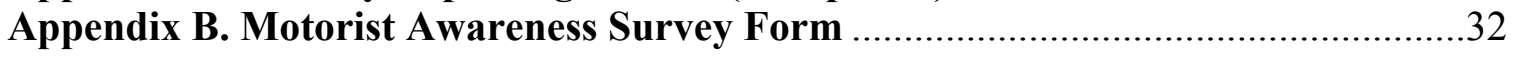

Appendix C: Missouri Seat Belt Observation Form .............................................3

Appendix D: Post-Program Survey for Participating Police Officers .......................34 


\section{List of Figures}

Figure 1. Observed Seat Belt Usage Rates in Missouri and in 15 States

That Upgraded Their Laws During the Recent HVE Mobilization

Period (1996-2007)

Figure 2. Observed Seat Belt Use in Missouri and in St. Louis County ...........................5

Figure 3. Historical Observed Seat Belt Usage in St. Louis County at

One Site in the Targeted Corridor and Countywide (2000-2008).....................

Figure 4. Historical Seat Belt Usage in St. Louis and Counties........................................9

Figure 5. Results of Awareness Surveys in Program and Control Areas.........................16

Figure 6. Results of Observational Surveys in Program and Control Areas ...................19

\section{List of Tables}

Table 1. Observed Usage Rates in Missouri and in 15 States That Have Upgraded Their SBU Laws to Allow for Primary

Enforcement: 1996-2007

Table 2. Enforcement Levels and Rates: St. Louis County Versus Benchmarks ...........13

Table 3. Results of Awareness Surveys in Program and Control Areas.........................16

Table 4. Results of Observational Surveys in Program and Control Areas ....................18 


\section{Background}

This report describes the characteristics and results of a high visibility corridor enforcement program conducted in St. Louis County, Missouri, that has a primary seat belt enforcement ordinance that covers unincorporated areas.

\section{Map 1. St. Louis County Showing Unincorporated Areas}

Unincorporated areas highlighted. Note that the City of St. Louis is not part of St. Louis County

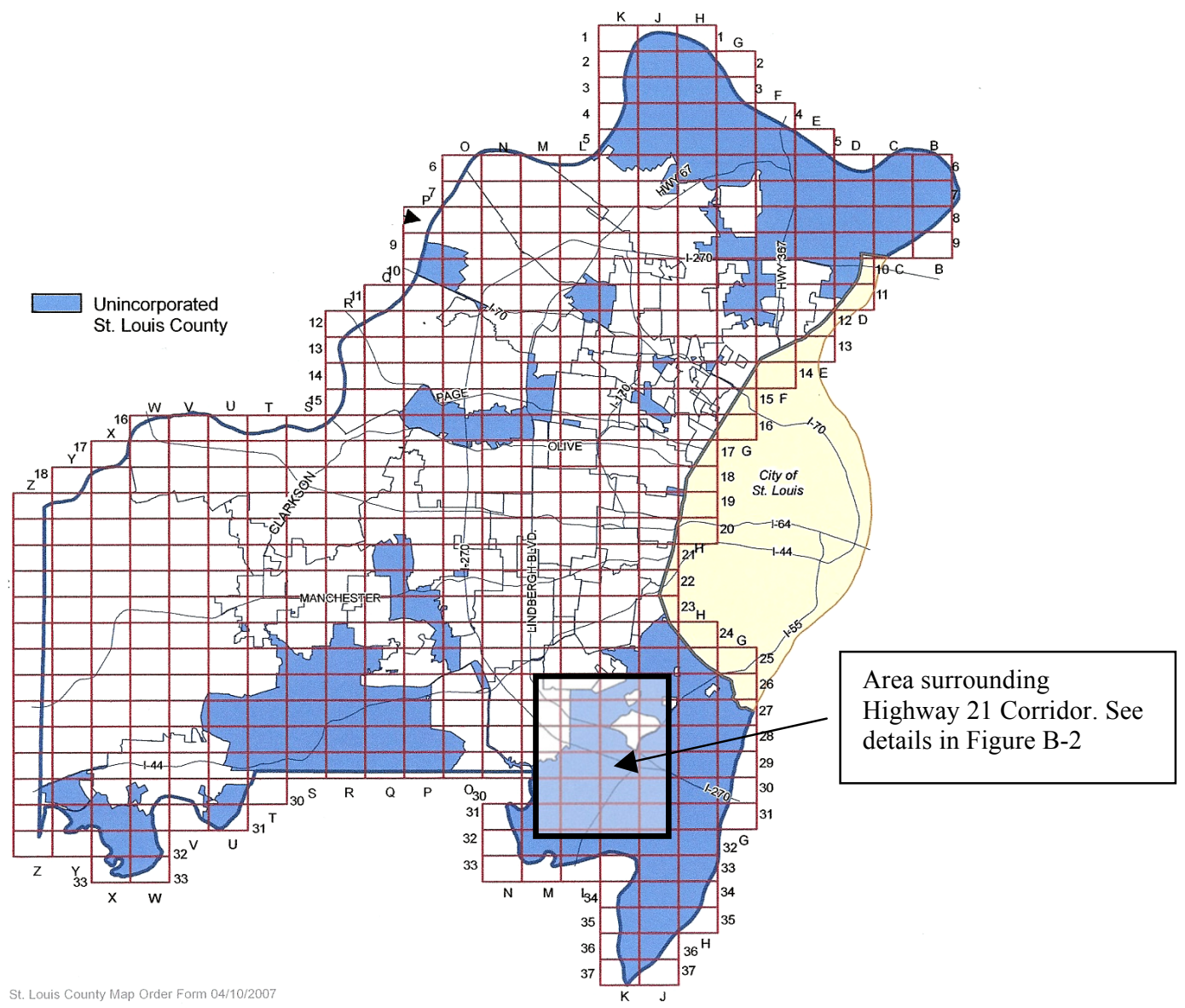

Missouri Experience. Missouri was the seventh State to adopt a seat belt usage law, doing so in September 1985. Since that time, however, the State has been unable to upgrade its secondary enforcement law. Following gains through 2005, statewide usage has remained unchanged at or about $77 \%$ for the past several years. In 2007, Missouri's usage was 5 points below the national rate of $82 \%$ and 8 points below the average rate of $85 \%$ in 15 States that have upgraded their seat belt laws since 1996. This plateau of usage at less than $80 \%$ has occurred in spite of regular and active participation in annual mobilizations.

St. Louis County Experience. St. Louis County has also participated regularly in high visibility enforcement (HVE) mobilizations over the past decade, experiencing gains 
through 2005 but a slight decline since that time. In March 2007, St. Louis County implemented a seat belt ordinance that allowed for traditional enforcement procedures. These changes allowed the new ordinance to be enforced using traditional traffic enforcement procedures. However, the ordinance was limited in scope in that it applied only to unincorporated areas of the county, which constitute less than one-third of the population and land area and that are scattered across the county. The largest unincorporated areas can be found in the northeast, south, and southeast regions.

Program and Control Corridors. In order to increase usage on St. Louis County roads, particularly on roadways with fatal or disabling injury crashes, the St. Louis County Police Department (SLCPD) conducted an intense and highly visible enforcement campaign along an 8-mile corridor on State Highway 21 (in the southeastern part of the county). This corridor was selected in part because there had been at least 8 fatal or disabling injury crashes along this roadway in recent years. A similar roadway, Highway 24, was selected in Jackson County (located across the State) to serve as a control or comparison site for evaluation purposes.

Map 2. Highway 21 Corridor - Tesson Ferry Road (St. Louis County) Traffic Corridor Selected for Intensified Enforcement, Publicity, and Observation Surveys Source Map Provided by MoDOT

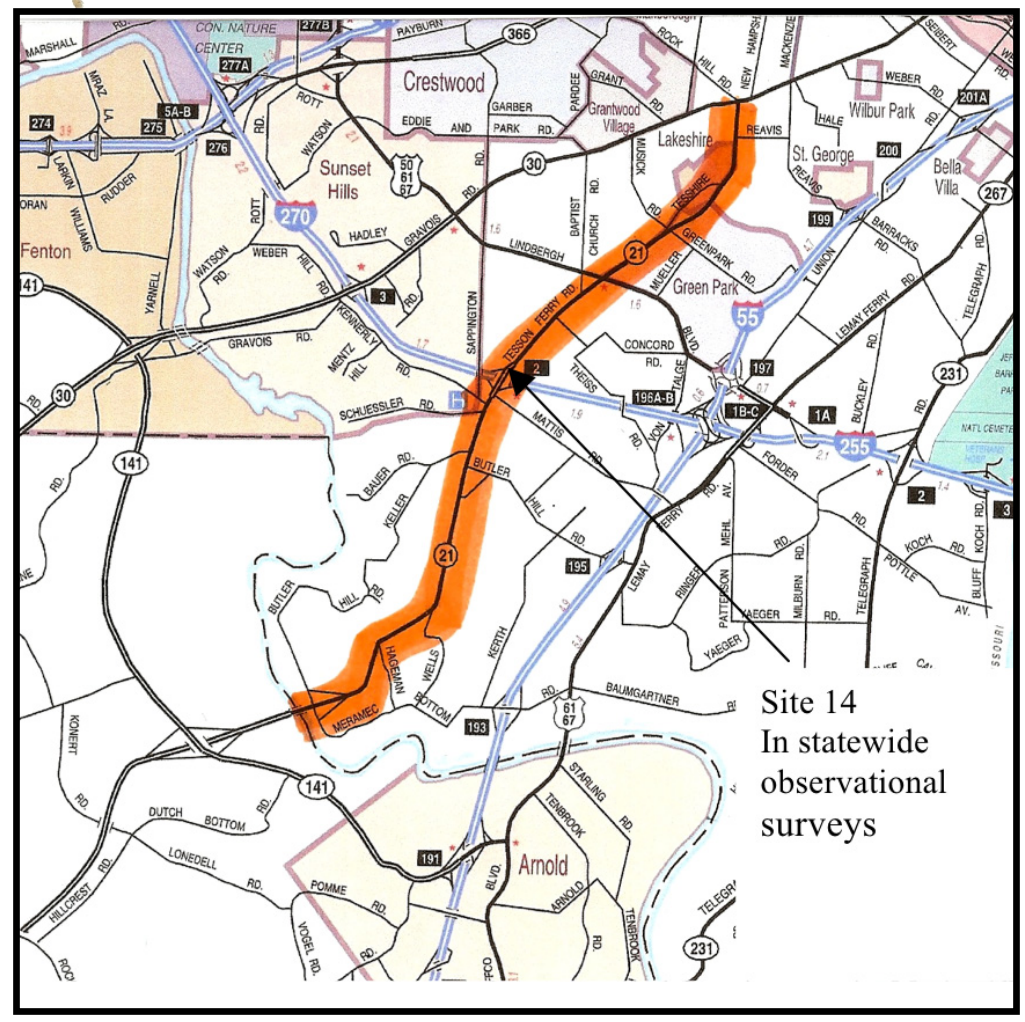




\section{Media}

The HVE program was implemented on November 17, 2008. A press release was issued three days prior to the start of the enforcement activity and a media event was held on the first day of the campaign. Messaging during the event focused on: (a) the lifesaving benefit of seat belts; (b) the purpose of the county seat belt ordinance; (c) efforts to enact a statewide primary seat belt law; (d) the intensive enforcement activity that was about to begin; and (e) the number and locations of roadway signs being used to alert the public. The press release and media event were intended to generate news stories in the local media. Associated with the two-week effort, State and county officials reported 10 news stories, evenly distributed among television, radio, and print media.

Nine variable message boards and six permanent signs were used along the 8-mile corridor to make the public aware of the ongoing enforcement activity. The variable message boards contained a variety of messages including: "Buckle Up - Seatbelt Law Enforced," "Click It or Ticket," and Buckle Up-It's the Law-Ordinance Enforced Ahead." All six permanent signs read "Buckle Up. It's the Law, County Ordinance 1217.095." There was no paid media and no public service media.

Map 3. Highway 24 Corridor (Jackson County)

Traffic Corridor Selected for Intensified Enforcement, Publicity, and Observation Surveys

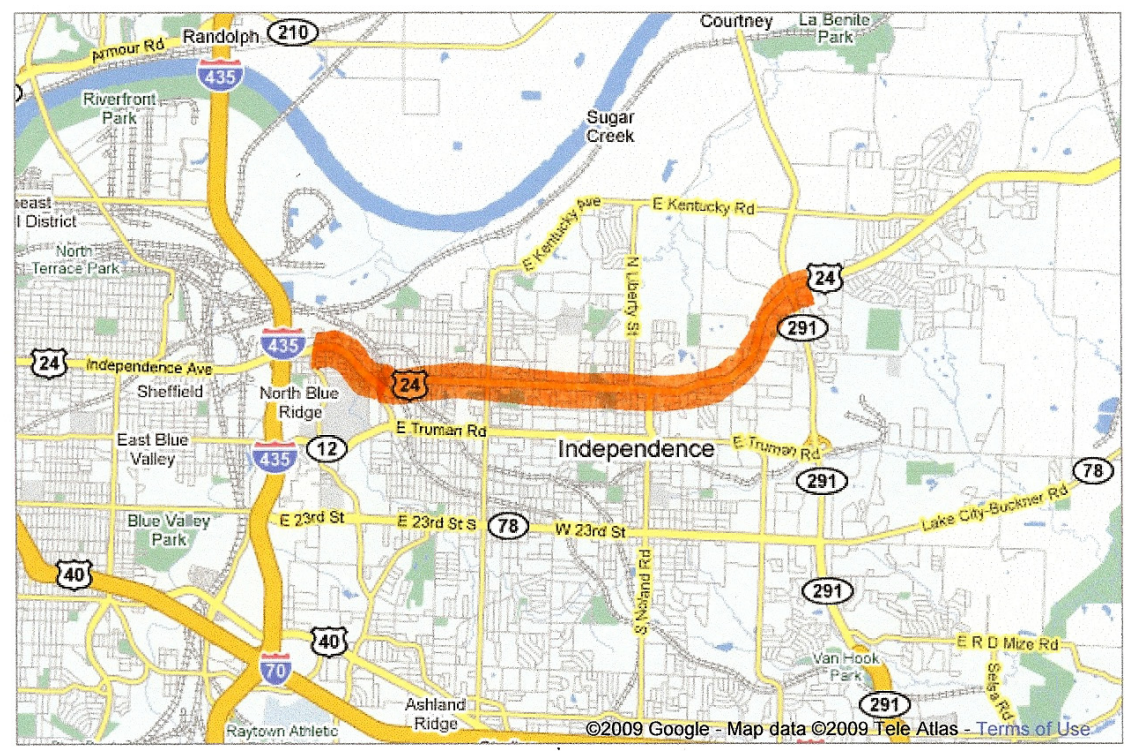

\section{Enforcement}

Enforcement consisted of both saturation patrols and enforcement zones with an emphasis on issuing citations rather than warnings. Enforcement occurred primarily during daylight hours but some enforcement occurred as late as midnight. Although overtime was involved, most enforcement occurred during regular patrol hours. 
The 13-day HVE effort included just over 500 total enforcement hours, 318 (64\%) of which were during regular patrols and $182(36 \%)$ of which were part of overtime activity. During these hours, all six officers of the SLCPD Highway Safety Unit plus a small group of additional officers saturated the targeted corridor, actively observing for seat belt violations. As a result, they issued a total of 991 citations and 140 warnings for seat belt violations, plus an additional 12 citations for child passenger safety law violations. Thus, the total number of "actions" or "contacts" for seat belt and child seat violations was just under 1,150 , with $88 \%$ of such actions resulting in citations issued.

A comparison of the number citations (1,131 seat belt plus child restraint) with the number of hours worked (500) provided a citation rate of approximately 2 citations per hour worked or, alternatively about 30 minutes worked for each citation issued. This rate is very high compared with the May 2008 CIOT average of 0.47 citations issued per hour worked $(637,211$ citations $\div 1,359,288$ hours worked $=0.47)$. In another comparison, enforcement as part of NHTSA's Rural Demonstration Program in Region 5 found a median citation rate of 1.2 citations per hour (alternatively, 50 minutes of enforcement for each citation issued), much closer to the St. Louis County rate of 2 citations per hour.

In addition to citations and warnings issued for these violations of occupant protection laws, many additional enforcement actions resulted from this HVE effort. They included 6 arrests for driving while intoxicated, 3 felony arrests, 3 fugitives apprehended, 30 uninsured motorist violations, and 25 speeding violations.

\section{Awareness}

There was consistent evidence of significant increases in indices of program awareness and in changes in perceptions that favored primary enforcement on the targeted corridor, Highway 21 in St. Louis County. Few such changes were found for the control corridor, Highway 24 in Jackson County. Following is a summary of these changes.

- Awareness of seat belt enforcement on Highway 21 increased from 16.5\% (pre-program) to $77.0 \%$ (post-program), a highly significant increase of 60.5 percentage points. Results from the surveys on Highway 24 showed a small but significant 9.3-point increase in awareness of seat belt enforcement. The increase in St. Louis County was 6.5 times the increase in Jackson County.

- The perceived risk of getting a ticket for riding unbuckled increased from $21.6 \%$ to $32.4 \%$ in the program area, a highly significant increase of 10.8 percentage points. There was a non-significant, 2.6-point decline in Jackson County. The difference in change between the program area increase and the control-area decline was 13.4 percentage points.

- The percentage of respondents who favored a primary law increased significantly from $63.1 \%$ to $69.6 \%$ in St. Louis County, a 6.5-point increase. There was a non-significant 5.6-point decline in Jackson County (from 61.3\% 
to $55.7 \%$ ). The difference between program area increase and the nonsignificant control-area decline was 12.1 percentage points.

- The percentage of respondents who thought that county police could enforce the seat belt law as a primary offense increased significantly from $61.5 \%$ to $69.4 \%$ in St. Louis County, a 7.9-point increase. No such increase was apparent in Jackson County. The difference between the program area controlarea changes was 7.0 percentage points.

- Although there was a slight increase in the proportion of St. Louis County respondents who thought that State Police could enforce the seat belt law as a primary law (from $65.7 \%$ to $70.4 \%$ ), this shift was not statistically significant and there was virtually no change among Jackson County respondents.

- In St. Louis County, the proportion who thought that the police enforced the law very strictly increased from $11.3 \%$ to $18.2 \%$, a significant increase of just under 7 percentage points. In Jackson County, there was a small, nonsignificant decline, from $19.1 \%$ to $18.0 \%$ in this proportion.

The consistency of pre-to-post trends is strongly indicative of the impact of the program on the Highway 21 corridor. Of particular importance were the findings that there was a significant increase in the proportion of St. Louis County respondents who thought that the seat belt law could be enforced as a primary law and that there was an increase in support for primary law enforcement associated with the program. 
Results of Awareness Surveys in Program and Control Areas.

\begin{tabular}{|c|c|c|c|c|c|c|}
\hline Index & County & $\begin{array}{c}\text { Pre } \\
\%\end{array}$ & $\begin{array}{c}\text { Post } \\
\%\end{array}$ & $\begin{array}{c}\text { Chg. } \\
\text { Pct. Pts. }\end{array}$ & $\mathbf{X}^{2}$ & p \\
\hline \multirow[t]{3}{*}{ Aware of SB Enforcement } & $\begin{array}{l}\text { St. Louis } \\
\qquad \mathrm{N}=\end{array}$ & $\begin{array}{r}16.5 \\
407\end{array}$ & $\begin{array}{r}77.0 \\
413\end{array}$ & 60.5 & 301.6 & $\begin{array}{c}<0.001 \\
* * *\end{array}$ \\
\hline & $\begin{array}{r}\text { Jackson } \\
\mathrm{N}=\end{array}$ & $\begin{array}{r}35.0 \\
394\end{array}$ & $\begin{array}{r}44.3 \\
395\end{array}$ & 9.3 & 7.095 & $\begin{array}{c}0.0077 \\
* *\end{array}$ \\
\hline & Program - Control & \multicolumn{5}{|c|}{51.2} \\
\hline \multirow[t]{3}{*}{ Perceive That Ticket Is Likely } & $\begin{array}{l}\text { St. Louis } \\
\mathrm{N}=\end{array}$ & $\begin{array}{r}21.6 \\
407\end{array}$ & $\begin{array}{r}32.4 \\
411\end{array}$ & 10.8 & 11.959 & $\begin{array}{c}<0.001 \\
* * *\end{array}$ \\
\hline & $\begin{array}{r}\text { Jackson } \\
\mathrm{N}=\end{array}$ & $\begin{array}{r}36.4 \\
393\end{array}$ & $\begin{array}{r}33.8 \\
399\end{array}$ & -2.6 & 0.566 & 0.452 \\
\hline & Program - Control & \multicolumn{5}{|c|}{13.4} \\
\hline \multirow[t]{3}{*}{ Support Primary Enforcement } & $\begin{array}{l}\text { St. Louis } \\
\qquad \mathrm{N}=\end{array}$ & $\begin{array}{r}63.1 \\
406\end{array}$ & $\begin{array}{r}69.6 \\
408\end{array}$ & 6.5 & 3.914 & $\begin{array}{c}0.048 \\
*\end{array}$ \\
\hline & $\begin{array}{r}\text { Jackson } \\
\mathrm{N}=\end{array}$ & $\begin{array}{r}61.3 \\
388\end{array}$ & $\begin{array}{r}55.7 \\
388\end{array}$ & -5.6 & 2.569 & 0.109 \\
\hline & Program - Control & \multicolumn{5}{|c|}{12.1} \\
\hline \multirow[t]{3}{*}{$\begin{array}{l}\text { Perceive That County Police Can } \\
\text { Enforce as a Primary Law }\end{array}$} & $\begin{array}{l}\text { St. Louis } \\
\qquad \mathrm{N}=\end{array}$ & $\begin{array}{r}61.5 \\
408\end{array}$ & $\begin{array}{r}69.4 \\
415\end{array}$ & 7.9 & 5.650 & $\begin{array}{l}0.017 \\
*\end{array}$ \\
\hline & $\begin{array}{r}\text { Jackson } \\
\mathrm{N}=\end{array}$ & $\begin{array}{r}49.9 \\
395\end{array}$ & $\begin{array}{r}50.8 \\
400\end{array}$ & 0.9 & 0.061 & 0.805 \\
\hline & Program - Control = & \multicolumn{5}{|c|}{7.0} \\
\hline \multirow[t]{3}{*}{$\begin{array}{r}\text { Perceive Strict Enforcement } \\
\text { Of Seat Belt Law }\end{array}$} & $\begin{array}{l}\text { St. Louis } \\
\qquad \mathrm{N}=\end{array}$ & $\begin{array}{r}11.3 \\
406\end{array}$ & $\begin{array}{r}18.2 \\
413\end{array}$ & 6.9 & 7.950 & $\begin{array}{c}0.006 \\
* *\end{array}$ \\
\hline & $\begin{array}{r}\text { Jackson } \\
\mathrm{N}=\end{array}$ & $\begin{array}{r}19.1 \\
393\end{array}$ & $\begin{array}{r}18.0 \\
400\end{array}$ & -1.1 & 0.154 & 0.695 \\
\hline & Program - Control = & \multicolumn{5}{|c|}{8.0} \\
\hline
\end{tabular}

Results of Awareness Surveys in Program and Control Areas

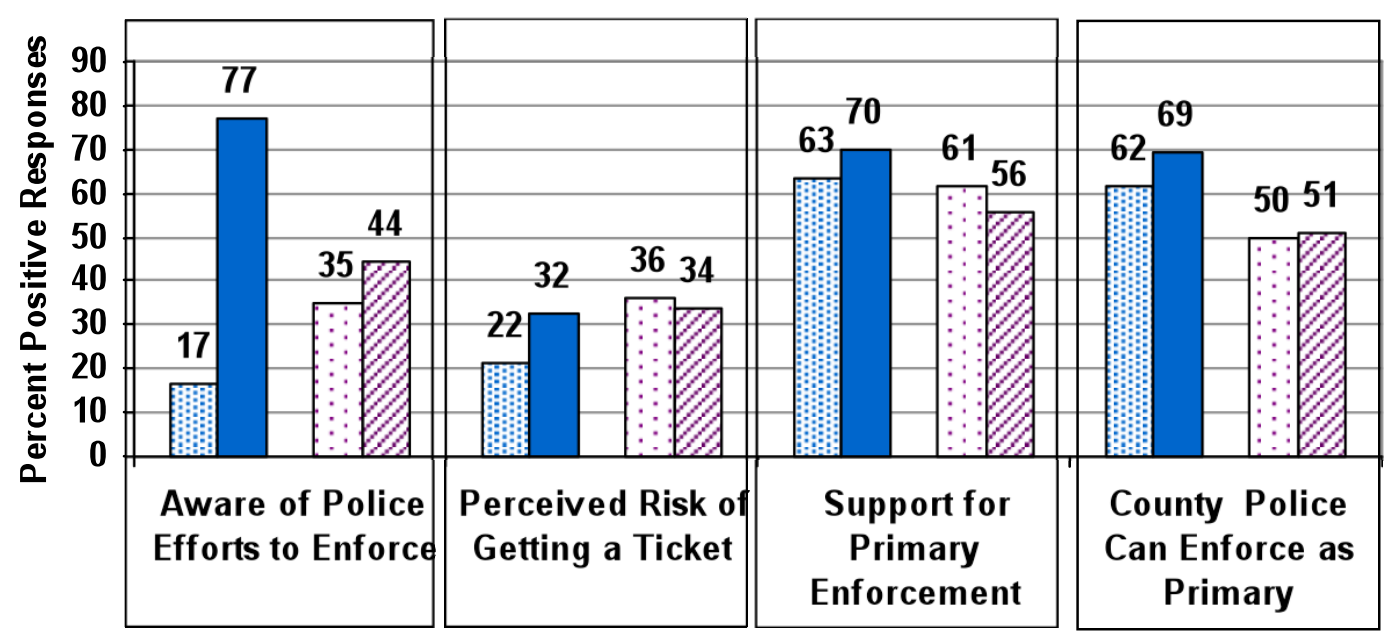

$\varpi$ Program (Pre) $\square$ Program (Post) $\square$ Control (Pre) $\square$ Control (Post 


\section{Changes in Observed Usage}

Mini-surveys conducted at 15 sites measured changes in observed seat belt use along the Highway 21 and 24 corridors. They were conducted just prior to the start of the enforcement period (November 10-13) and immediately after its conclusion (December 1-4). Observations of 25,877 front-seat, passenger-vehicle occupants showed a significant 4.9-percentage-point increase in usage along the Highway 21 corridor (from $83.3 \%$ to $88.2 \%$ ) and a small, but significant 2.2-point decline on Highway 24. Overall, the difference in change between these two areas was 7.1 percentage points (see table below). On Highway 21, passenger use increased by 6 points (to nearly $90 \%$ ) and driver use increased by 4.7 points.

\section{Results of Observational Surveys in Program and Control Areas.}

\begin{tabular}{|c|c|c|c|c|c|c|}
\hline Index & County & $\begin{array}{l}\text { Pre } \\
\%\end{array}$ & $\begin{array}{c}\text { Post } \\
\%\end{array}$ & $\begin{array}{c}\text { Chg. } \\
\text { Pct. Pts. }\end{array}$ & $X^{2}$ & p \\
\hline \multirow[t]{3}{*}{ Drivers } & $\begin{array}{l}\text { St. Louis County } \\
\qquad \mathrm{N}=\end{array}$ & $\begin{array}{r}83.3 \\
6,425\end{array}$ & $\begin{array}{r}88.0 \\
6,851\end{array}$ & 4.7 & 60.28 & $<0.0001$ \\
\hline & $\begin{array}{r}\text { Jackson County } \\
\mathrm{N}=\end{array}$ & $\begin{array}{r}58.8 \\
4,796\end{array}$ & $\begin{array}{r}56.5 \\
2,247\end{array}$ & -2.3 & 4.679 & 0.0305 \\
\hline & Program - Control & \multicolumn{5}{|c|}{7.0} \\
\hline \multirow[t]{3}{*}{ Passengers } & $\begin{array}{r}\text { St. Louis County } \\
\mathrm{N}=\end{array}$ & $\begin{array}{r}83.5 \\
1,119\end{array}$ & $\begin{array}{r}89.4 \\
1,059\end{array}$ & 6.0 & 16.39 & $<0.0001$ \\
\hline & $\begin{array}{r}\text { Jackson County } \\
\mathrm{N}=\end{array}$ & $\begin{array}{r}48.3 \\
1.098\end{array}$ & $\begin{array}{r}45.0 \\
854\end{array}$ & -3.3 & 2.107 & 0.1466 \\
\hline & Program - Control & \multicolumn{5}{|c|}{9.3} \\
\hline \multirow[t]{3}{*}{ All Occupants } & $\begin{array}{l}\text { St. Louis County } \\
\qquad \mathrm{N}=\end{array}$ & $\begin{array}{r}83.3 \\
7.544\end{array}$ & $\begin{array}{r}88.2 \\
7,910\end{array}$ & 4.9 & 75.55 & $<0.0001$ \\
\hline & $\begin{array}{r}\text { Jackson County } \\
\mathrm{N}=\end{array}$ & $\begin{array}{r}56.9 \\
5,894\end{array}$ & $\begin{array}{r}54.6 \\
4,815\end{array}$ & -2.2 & 5.262 & 0.0217 \\
\hline & Program - Control & \multicolumn{5}{|c|}{7.1} \\
\hline
\end{tabular}

\footnotetext{
${ }^{1}$ Note that all rates and changes are rounded.
} 
Figure 6. Results of Observational Surveys in Program and Control Areas

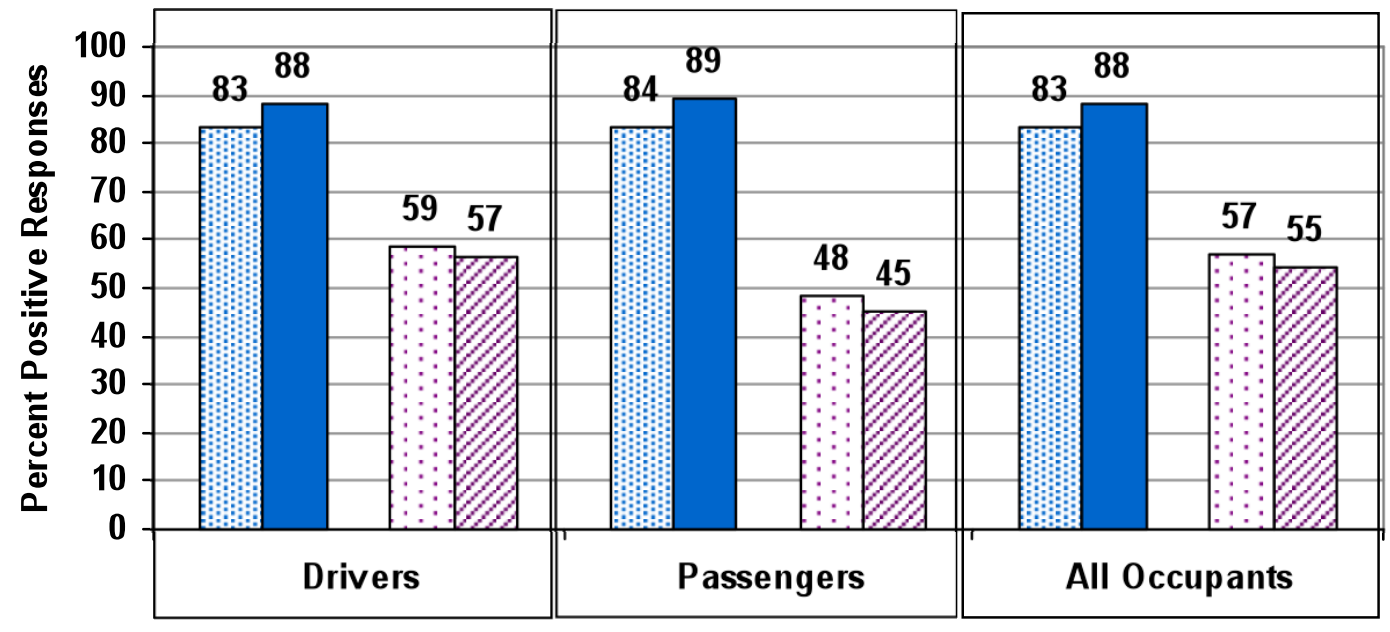

๑ Program (Pre) ๑ Program (Post) $\square$ Control (Pre) $\square$ Control (Post

\section{Officer and Motorist Reactions}

Prior to conducting this campaign, officers in the SLCDP Highway Safety Unit said there was a major positive reaction the passage of the county's primary ordinance in 2007. They felt that the county ordinance greatly facilitated their ability to issue tickets for seat belt violations. However, several officers suggested that the low fine (\$10) limited its impact to some extent. Most officers were still writing seat belt tickets but most often along with citations for other violations. A second group of officers, not from the Highway Safety Unit, showed slightly less enthusiasm for enforcing the seat belt ordinance in part because it was not uniformly in effect across the county. All these officers supported having a statewide primary law. They said such a law would provide "another tool in their chest" for increasing seat belt use. These also felt that the fine should be increased to at least $\$ 25$.

After the campaign, officers in the Highway Safety Unit reported that the enforcement effort had gone very well and that it became much harder to find violators toward the end of the campaign. They said most motorists understood why county police were enforcing the law and supported their efforts. One officer said most of the motorists ticketed did not even know that the county had a primary ordinance.

Every officer in the unit endorsed the county ordinance whole-heartedly and thought that the State should enact a statewide primary law. Two said they were now more aware of the ordinance and were enforcing it more frequently than before, particularly as a primary law. Several said they thought the fine should be increased from $\$ 10$ to a minimum of $\$ 25$. With regard to how to increase usage or at least maintain a high rate in the county, these officers suggested (a) enacting a statewide primary law; (b) publicizing the law and their efforts; (c) increasing the fine; and (d) conducting additional enforcement campaigns. Some additional observations were that passengers typically didn't know the 
law applied to them as well as to drivers; most teens didn't know that not wearing a seat belt was a violation of their restricted driver's licenses; and many motorists were not aware of the county's primary ordinance prior to this campaign.

In summary, this corridor program was characterized by a "strong" enforcement effort, with approximately two citations issued per officer hour worked. Due to a lack of time and resources, there was no paid media and little or no broadcast media. The results showed a significant increase in all indices of public awareness and perception and a significant increase in observed usage in the targeted corridor. There were significant increases in usage among pickup truck occupants as well as among occupants of other vehicles. This is important in that occupants of pickup trucks have historically had lower observed usage than occupants of other vehicles in Missouri.

Based upon three different estimation scenarios, it is estimated that Missouri would save between 30 and 70 lives, would have between 400 and 900 fewer serious crash injuries, and would realize $\$ 110$ million to $\$ 215$ million in lower economic costs annually if it enacted a statewide primary law upgrade and implemented regular HVE programs, similar to the program implemented in St. Louis County. 


\section{Background}

\section{A. Seat Belts and Seat Belt Use Laws}

Manual three-point seatbelts have repeatedly been shown to be effective in reducing fatalities among occupants of passenger vehicles (cars, light trucks, and vans). A recent evaluation of this effectiveness (Kahane, 2004) found that, compared with unrestrained front-seat occupants, these safety devices reduce fatality risk among restrained, front-seat occupants by $45 \%$ in passenger cars and by $60 \%$ in light trucks and vans. These estimates are identical to those from earlier analyses of NHTSA's Fatality Analysis Reporting System (FARS) database (Kahane, 2000).

Obviously, seat belts can have no effectiveness if they are not worn and it has proved to be difficult to get high seat belt usage rates, particularly among high-risk groups. It has taken 25 years to increase the national observed usage rate from about $11 \%$ in 1980 to $80 \%$ in 2005 . Even with this accomplishment, however, many higher risk occupants such as young males, drinking drivers, and occupants on the roadway late at night still do not buckle up (Nichols \& Ledingham, 2008).

To date, the most effective means for increasing seat belt usage among occupants of passenger vehicles has been a combination of seat belt laws and high visibility enforcement. Prior to 1990, the enactment of laws resulted in observed usage rates that leveled off at just under $50 \%$ in States that required secondary enforcement procedures and at just over $60 \%$ in States that allowed for traditional enforcement procedures. The latter are often referred to as "primary" enforcement laws, but that label conveys a misconception that they are somehow different from other traffic laws in the type of enforcement permitted. In fact, they allow for the traditional practice of stopping and citing an operator for an observed violation of the law. "Secondary" laws represent a deviation from traditional enforcement, requiring that another violation be observed prior to stopping a vehicle for a seat belt violation.

More important than increases in observed seat belt usage, increases in usage among people involved in fatal crashes have also been associated with seat belt laws and these increases have been higher in primary law States than in secondary law States. Increased usage among people involved in fatal crashes is essential to reducing fatalities and injuries since it reflects usage among those occupants who are actually involved in serious and fatal crashes.

\section{B. Relative Effectiveness of Primary and Secondary Enforcement Laws}

Use rates in primary law States have historically been 10 to 15 percentage points higher than in secondary law States. That was the case before 1990, when there was very little enforcement of seat belt laws, and it has been the case since 1990, when high visibility enforcement (HVE) has become more commonplace. This increase in HVE is due in part to national mobilizations, first implemented in 1997 as Operation ABC (시ways Buckle 
Children) and more recently as part of NHTSA's Click It or Ticket (CIOT) Program. During the past 12 years, national usage has increased by about 22 percentage points, from about $61 \%$ in 1996 to $83 \%$ in 2008 (NHTSA, 2008a, 2008b, 2007; Nichols \& Jones, under review). The greatest increases have been in States that upgraded their laws to allow for primary enforcement and, at the same time, have participated in HVE mobilizations (Nichols \& Ledingham, 2008). Two such States were Washington and Illinois. Both upgraded their laws after 1996 and participated regularly in national (and statewide) HVE mobilizations. Associated with these upgrades and HVE efforts, these two States experienced 27- to 28-percentage-point increases in observed usage through $2007 .^{2}$ More important, usage among occupants involved in potentially fatal crashes (UPFC) increased by 14 points in Washington and by 17 points in Illinois. ${ }^{3}$

Washington and Illinois are not isolated examples of large increases in usage associated with the combination of law upgrades and HVE. Of the 15 States that upgraded their laws from 1997 through 2007 and participated in annual mobilizations, there was a 26-point average increase in observed usage through 2007. Most of these States (12 of 15) achieved usage rates exceeding $80 \%$ by 2007 and one-third ( 5 of 15 ) reached $90 \%$ or greater usage. Only three recent upgrade States have not been able to achieve $80 \%$ usage, South Carolina, Kentucky, and Mississippi. Table 1 shows observed usage for all 15 States, from 1996 through 2007.

\section{Missouri's SBU Law and Changes in Seat Belt Usage}

Missouri was an early adopter of seat belt laws. In fact, it was the seventh State to enact a SBU law. It was implemented in September 1985 and it required secondary enforcement procedures. Since that time, observed usage in Missouri has increased by 67 percentage points, from about $10 \%$ in 1984 to $77 \%$ in 2007 . During the recent national mobilization period, Missouri usage increased by 19 points, from 58\% in 1996 to $77 \%$ in 2007. Even though baseline rates were nearly identical, the 19-point increase in Missouri is 7 points less than the average increase seen among States that upgraded their laws (see Table A-1). ${ }^{4}$

Of greater current concern is the fact that usage has remained unchanged at or about $77 \%$ for the past several years, 5 points below the 2007 national rate of $82 \%$ and 8 points below the $85 \%$ average in the fifteen upgrade States. This stagnation of usage at under $80 \%$ is in spite of regular and active participation in annual CIOT mobilizations and

\footnotetext{
${ }^{2} 2007$ was the last year for which published State rates were available at this writing (NHTSA, 2008a). Observed usage in Washington State had increased from 79\% in 1996 to $96.4 \%$ in 2007. Usage in Illinois had increased from $62 \%$ in 1996 to $90.1 \%$ in 2007. 1996 rates were obtained from NHTSA archives. They are State-reported rates as adjusted by NHTSA for factors such as rural sites and vehicle types included. ${ }^{3}$ Changes in UPFC were calculated based upon the number of restrained occupants killed $(\mathrm{F})$ and the total number of occupants killed in these States in 1996 and 2007. From these numbers, an estimate of total restrained occupants saved was calculated by the formula: Saved $=\mathrm{FE} /(1-\mathrm{E})$, where $\mathrm{E}$ is the estimated effectiveness of seat belts in reducing fatalities and injuries. UPFC $=($ \# Restrained Killed + \# Saved $) \div$ (Total \# Killed + \# Saved). UPFC can also be calculated by means of known usage among fatalities and NHTSA's Belt Use software, which is part of its MVS package available on the Web at nhtsa.dot.gov.

${ }^{4}$ During this same period, UPFC increased by 9 percentage points in Missouri, considerably less than the 14- to 17-point increases seen in Illinois and Washington.
} 
recent participation in a special Buckle Up in Your Truck (BUIYT) demonstration program to increase seat belt use among occupants of pickup trucks (Nichols, Tison, Solomon, Ledingham, Preusser, \& Siegler, 2009).

Table 1. Observed Usage Rates in Missouri and in 15 States That Have Upgraded Their SBU Laws to Allow for Primary Enforcement: 1996-2007

\begin{tabular}{|c|c|c|c|c|c|c|c|c|c|c|c|c|c|c|}
\hline \multirow{2}{*}{$\begin{array}{l}\text { Law } \\
\text { Year }\end{array}$} & \multirow[b]{2}{*}{ State } & \multicolumn{12}{|c|}{ Observed Seat Belt Usage (Percent) } & \multirow{2}{*}{$\begin{array}{l}\text { Pct. Pt. } \\
\text { Chg. }\end{array}$} \\
\hline & & 1996 & 1997 & 1998 & 1999 & 2000 & 2001 & 2002 & 2003 & 2004 & 2005 & 2006 & 2007 & \\
\hline 1997 & DC & 55 & 64 & 82 & 78 & 83 & 84 & 85 & 85 & 87 & 89 & 85 & 87 & 32 \\
\hline 1997 & MD & 70 & 71 & 83 & 83 & 85 & 83 & 86 & 88 & 89 & 91 & 91 & 93 & 23 \\
\hline 1997 & OK & 48 & 60 & 56 & 61 & 68 & 68 & 70 & 77 & 80 & 83 & 84 & 83 & 35 \\
\hline 1998 & IN & 53 & 53 & 62 & 57 & 62 & 67 & 72 & 82 & 83 & 81 & 84 & 88 & 35 \\
\hline 1999 & $\mathbf{A L}$ & 54 & 52 & 52 & 58 & 71 & 79 & 79 & 77 & 80 & 82 & 83 & 82 & 28 \\
\hline 2000 & $\mathbf{N J}$ & 59 & 60 & 63 & 63 & 74 & 78 & 81 & 81 & 82 & 86 & 90 & 91 & 32 \\
\hline 2000 & MI & 66 & 67 & 70 & 70 & 84 & 82 & 83 & 85 & 91 & 93 & 94 & 94 & 28 \\
\hline 2002 & WA & 79 & 77 & 79 & 81 & 82 & 83 & 93 & 95 & 94 & 95 & 96 & 96 & 17 \\
\hline 2003 & IL & 62 & 62 & 65 & 66 & 70 & 71 & 74 & 80 & 83 & 86 & 88 & 90 & 28 \\
\hline 2003 & DE & 62 & 59 & 62 & 64 & 66 & 67 & 71 & 75 & 82 & 84 & 86 & 87 & 25 \\
\hline 2004 & TN & 60 & 58 & 57 & 61 & 59 & 68 & 67 & 69 & 72 & 74 & 79 & 80 & 20 \\
\hline 2005 & SC & 61 & 61 & 65 & 65 & 74 & 70 & 66 & 73 & 66 & 70 & 73 & 75 & 14 \\
\hline 2006 & $\mathbf{A K}$ & 53 & 56 & 57 & 61 & 61 & 63 & 66 & 79 & 77 & 78 & 83 & 82 & 29 \\
\hline 2006 & MS & 44 & 46 & 58 & 55 & 50 & 62 & 62 & 62 & 63 & 61 & 74 & 72 & 28 \\
\hline 2007 & KY & 54 & 53 & 54 & 59 & 60 & 62 & 62 & 66 & 66 & 67 & 67 & 72 & 18 \\
\hline \multicolumn{2}{|c|}{ Upgrade Ave } & 59 & 60 & 64 & 65 & 70 & 72 & 74 & 78 & 80 & 81 & 84 & 85 & 26 \\
\hline \multicolumn{2}{|c|}{ U.S. Rate } & 61 & $\mathbf{n} / \mathbf{a}$ & 70 & 67 & 71 & 73 & 75 & 79 & 80 & 82 & 81 & 82 & 21 \\
\hline \multicolumn{2}{|c|}{ MO Rate } & 58 & 63 & 60 & 61 & 68 & 68 & 69 & 73 & 76 & 77 & 75 & 77 & 19 \\
\hline
\end{tabular}

In summary, Missouri was an early adopter of a seat belt law but the State has been unable to upgrade its secondary enforcement law. Further, it appears that HVE efforts have not resulted in as great an impact in Missouri as they have in 15 law upgrade States. Usage in Missouri has stabilized at less than $80 \%$ and, as Figure 1 suggests, the gap between usage in Missouri and in these upgrade States has widened in recent years. 
Figure 1. Observed Seat Belt Usage Rates in Missouri and in 15 States That Upgraded Their Laws During the Recent HVE Mobilization Period (1996-2007)

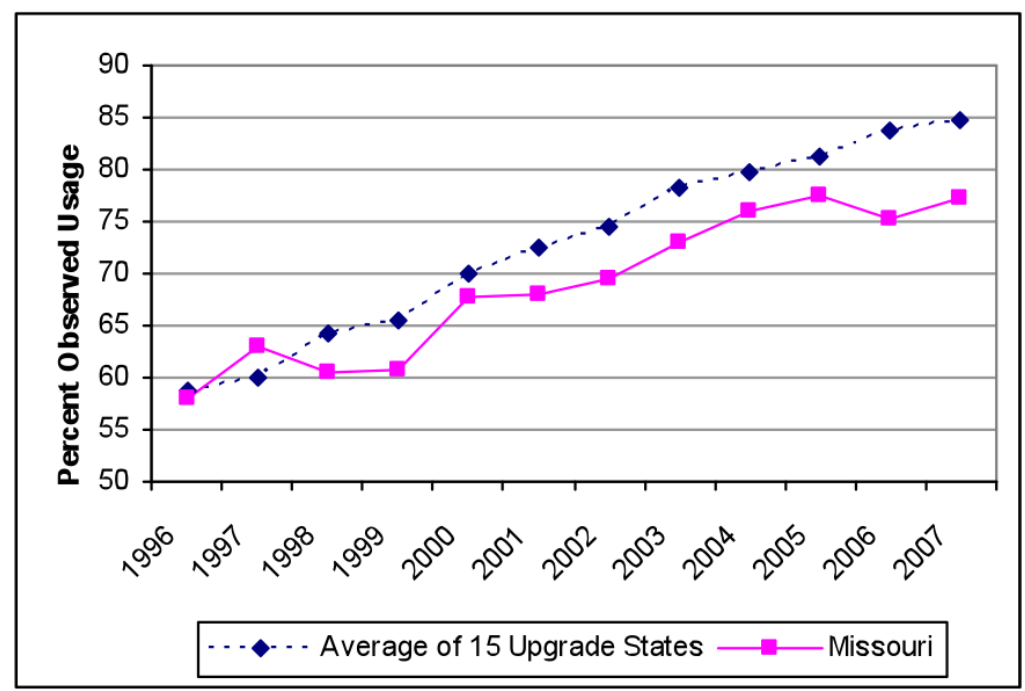

\section{A Primary Enforcement Ordinance in St. Louis County}

St. Louis County is the most populous county in Missouri, with a population of just under 1 million in 2007. It is part of the larger St. Louis metropolitan area, which has approximately 3 million residents. Consistent with its population size, the county has large numbers of fatal and serious injury crashes within its boundaries. Missouri Department of Transportation (MoDOT) statistics show that the county ranks second among all Missouri counties in the number of fatal traffic crashes (about 56 per year from 2005 through 2007) and first in the number of disabling-injury crashes (about 540 per year during the same time period). Based on statewide data from NHTSA's Fatality Analysis Reporting System (FARS), an estimated 65\% of the fatalities in St. Louis County likely involve unbuckled occupants. ${ }^{5}$

St. Louis County has regularly participated in HVE mobilizations over the past decade. With regard to seat belt use, data from 23 sites that are part of Missouri's annual statewide survey suggest that countywide usage increased through 2005 but has trended downward since that time, vacillating between $75 \%$ and $81 \%$. There was a brief increase in 2007, possibly associated with implementation of a primary seat belt ordinance, but this increase was followed by a decline in 2008, leaving the (unweighted) St. Louis County rate nearly identical to the statewide rate (75-76\%). Neither rate has shown any evidence of an upward trend since 2005 .

\footnotetext{
${ }^{5}$ This statement is based on statewide estimates. According to FARS, 32\% of 2,000 fatalities among passenger vehicle occupants were known to be buckled up at the time of the fatal crashes in 2007. Eliminating unknowns from the total, this translates to an estimated $35 \%$ buckled and $65 \%$ unbuckled.
} 


\section{Figure 2. Observed Seat Belt Use in Missouri and in St. Louis County}

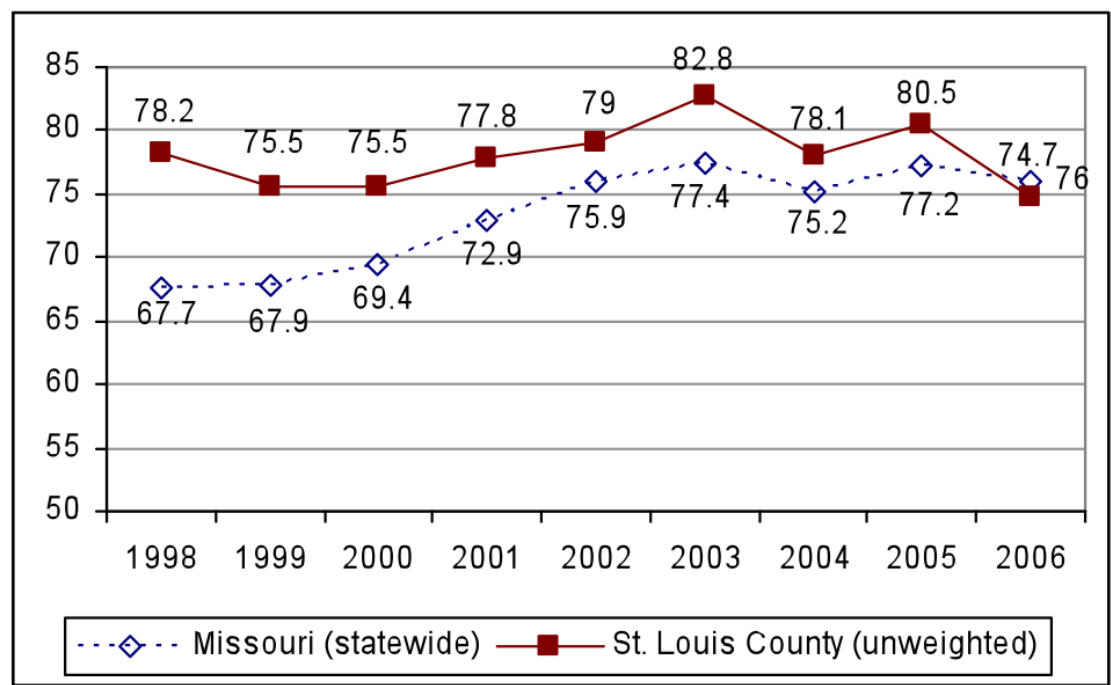

In March 2007, the St. Louis County Council implemented an ordinance (1217.095) that allowed for traditional enforcement procedures of the seat belt law in unincorporated areas. The wording of this ordinance was identical to the wording of the State seat belt law except that the following sentences were removed:

"No person shall be stopped, inspected, or detained solely to determine compliance with this subsection." and

"Noncompliance with this subsection shall not constitute probable cause for violation of any other provision of law."

Again, these changes allowed the new ordinance to be enforced using traditional traffic enforcement procedures but only in unincorporated areas of the county, which constitute less than one-third of the population and land area of the County and which are scattered across the county. The largest unincorporated areas can be found in the northeast, south, and southeast regions (see Map 1).

It is not clear to what extent the new ordinance was enforced after it was implemented. Officers interviewed as part of this evaluation said they were notified with regard to the new ordinance and that they did enforce seat belt violations more frequently immediately after the ordinance was put into effect. They also said there was some initial publicity for the new ordinance in the form of permanent road signs. However, these officers also pointed out that the fine for a violation remained at $\$ 10$ (the same as for the State law) and that they frequently wrote seat belt citations in addition to other citations (as would be the case with a secondary law). 


\section{E. Assessing the Impact of the Ordinance}

Early in 2008, about one year after its implementation, Federal and State safety officials began to assess the impact of the new seat belt ordinance. An initial review found very little information regarding enforcement activity, publicity, public awareness, or seat belt use before and after implementation of the law, particularly in the unincorporated areas covered by the ordinance. Further, since only about one-third of the population and land area of the county was covered by the ordinance and because these covered areas were dispersed across the county, a retrospective evaluation of the ordinance would likely be equivocal at best.

Based upon discussions with State and local officials, however, there was considerable interest among State and county officials in conducting more intense and visible enforcement within areas covered by the new ordinance and measuring the impact of such an effort. It was thought that a significant increase in usage associated with HVE in an unincorporated area would provide a benchmark for what could be achieved in other areas where such an ordinance was in effect or could be implemented and for what could be achieved statewide if a primary seat belt law was enacted and enforced. 


\section{The Program}

\section{A. The Corridor Program Approach}

The approach for this HVE effort was modeled after a corridor program reported by Ledingham, Tison, Casanova, and Preusser (under review). This was a program conducted in Queens, New York, in which a traffic corridor was identified where enforcement could be intensified; where relatively low-cost variable message boards, signs, and posters could be used to publicize the enforcement; and where observational surveys could be safely conducted. This model fit the St. Louis County situation in that little time was available for media development and no funds were available for paid media placement.

In the New York program, seat belt usage was observed and public awareness surveys were conducted within the targeted corridor in Queens and in a control corridor located in the Bronx. Baseline usage was high in this urban setting, averaging about $88 \%$. Still, observations documented a small but significant increase in conjunction with the first wave of HVE ( +2 points) and a larger increase associated with the final wave ( +4 points). These increases in observed seat belt use were simultaneous with measured increases in the public's awareness of the enforcement program.

\section{B. Problem Identification: Selecting a Target Corridor}

A first step in the process of implementing the St. Louis County program was to find a roadway with high rates of fatal and disabling injury crashes, where enforcement could be readily and visibly conducted, and where seat belt usage could be safely observed. Crash statistics provided by MoDOT showed several high-risk roadways in unincorporated areas of the county. They included segments on Interstate Highways I-44, I-55, I-70, and I-270, and on several State highways, including Missouri Highways 21, 61,141 , and 231. Several of these road segments were located in the southern part of the county where two of the largest unincorporated areas were located.

State Highway 21 was particularly attractive as a potential program site because there had been at least 8 fatal or disabling injury crashes along this roadway from 2005 to September 2008. In addition, there was high traffic volume, with two lanes of traffic in each direction, and there were relatively moderate speed limits on this roadway. Based on these data, an 8-mile section of Highway 21, also known as Tesson Ferry Road, was chosen for the HVE program (see Map 2)

\section{Historical Usage Rates on Highway 21}

Observational sites in the Missouri statewide survey included one site on Highway 21 (Site \# 14) that had been included in the annual seat belt survey at least since 2000. It was located at the intersection of Interstate 270 and Highway 21, near the center of the targeted 8-mile segment, extending from the southern county line north to Highway 30. 
Figure 3. Historical Observed Seat Belt Usage in St. Louis County, Missouri At One Site in the Targeted Corridor and Countywide $(2000-2008)$

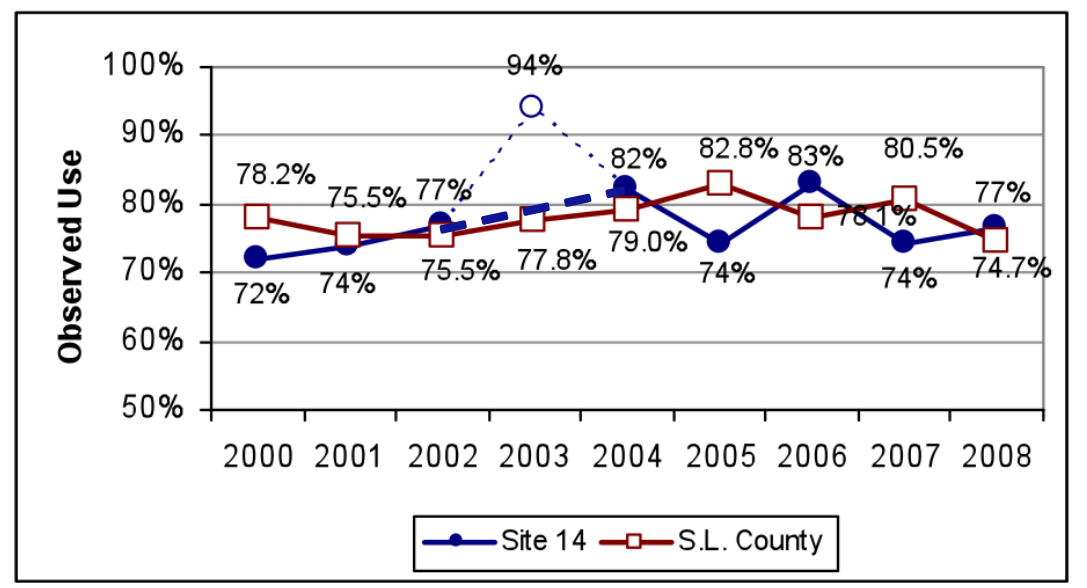

Figure 3 shows the historical usage rates observed at this site from 2000 to 2008. Disregarding what appears to be an abnormally high rate in 2003, there was a steady increase in usage through 2004, followed by more variable rates from 2004 through 2008. The statewide survey contractors (Central Missouri State University) observed seat belt usage among 77\% of all front-seat passengers in May 2008. Overall, the 8-year trend at this site was relatively similar to the countywide trend and there did not appear to be any upward trend in usage in recent years. This was important from the standpoint of measuring change associated with an HVE intervention.

\section{Selection of a Comparison Corridor}

Another corridor that would not likely be affected by the intervention in St. Louis County was needed as a control site. Rather than selecting a nearby county, Jackson County on the western border of the State was chosen as the comparison site. It is the second largest county (St. Louis County has the largest population) and is located at the opposite (western) boundary of the State as St. Louis County, which is on the eastern boundary. Since 2005, Jackson County has had the highest number of fatal crashes (St. Louis County had the second highest number) and the second highest number of disabling injury crashes (St. Louis County had the highest number) of any county in the State. Like St. Louis County, much of Jackson County is urban or suburban and, with Kansas City within its borders, it has several State Highways that serve as commuter arteries, similar to Highway 21 in St. Louis County.

Figure 4 shows historical usage data from statewide survey sites located in St. Louis and Jackson counties. The sites located in Jackson County historically have had lower rates of observed usage than sites located in St. Louis County. However, according to these observational data, usage was relatively comparable in these two counties in 2006 and $2007 .^{6}$

\footnotetext{
${ }^{6}$ No 2008 usage data were available for Jackson County at the time of program and control area selection.
} 
Two Jackson County roadways similar to the Highway 21 corridor in terms of function and bordering Kansas City were examined. They were Highway 24, from Kansas City west/northwest through Independence and beyond; and Highway 50, from Kansas City west/southwest through Lee's Summit and beyond. Both roadways carried commuter traffic to and from Kansas City.

A trained observer was sent to Jackson County to examine these two roadways and, based upon the information regarding roadway configuration, posted speed limits, and the presence of locations where seat belt use could be safely observed, a section of Highway 24 from Blue Ridge Boulevard (on the west) to East Bundschu Road (on the east), was selected as the control/comparison corridor.

\section{Figure 4. Historical Seat Belt Usage in St. Louis and Jackson Counties}

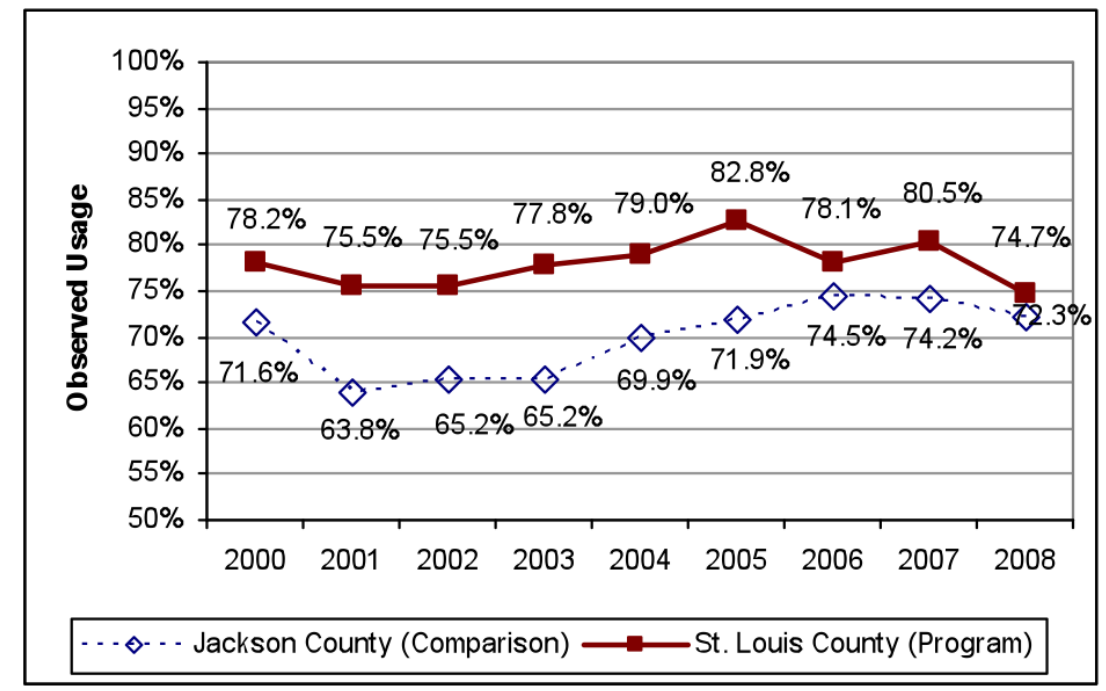

\section{E. Development of the St. Louis County HVE Program}

The development of a HVE program in St. Louis County was facilitated by a series of conference calls, beginning on September 24, 2008, and the subsequent formation of an informal planning group that included the St. Louis County Police Department (SLCPD); a training officer with the Chesterfield Police Department; State and local MoDOT officials; NHTSA's Region 7 office; and the contractor.

A first step in the development process was to obtain the commitment of the SLCPD command and to inform key officials in State and local government. They included the chief of the SLCPD; members of the Missouri Coalition for Roadway Safety; members of the St. Louis County Council (from which the ordinance emerged); and appropriate MoDOT officials, particularly the State Highway Safety Division and legislative affairs personnel. Approval by these entities provided the "political permission" to proceed with the planning and implementation process. 
Date. One of the first objectives of the planning group was to select a date for program implementation. Following a brief period of discussion, the group chose November 17 to November 30 as the program period. This left just under 8 weeks to develop and implement the enforcement, publicity, and evaluation components. However, it also allowed for an opportunity to have results in hand early in 2009.

Enforcement. The sergeant in charge of the SLCPD Highway Safety Unit developed an enforcement approach that included a combination of saturation patrols and enforcement zones $^{7}$ using regular and overtime hours. He and his officers decided to focus their efforts on the entire 8-mile corridor, from the county line on the south to the intersection with Highway 30 on the north. Emphasis would be placed on the issuance of tickets, rather than warnings, and, while most of the enforcement would take place during daylight hours, some efforts would be conducted at night.

Training and Funding. The training officer from the Chesterfield police department coordinated with the sergeant in charge of the SLCPD Highway Safety Unit to provide Traffic Occupant Protection Strategies (TOPS) training/orientation for all six officers in the unit. The Highway Safety Unit, in turn, developed enforcement plans and coordinated with the local Coalition for Roadway Safety to request funding for overtime to supplement regular enforcement activity. The Highway Safety Unit developed an enforcement approach that consisted of a combination of enforcement zones and saturation patrols, conducted during both regular and overtime hours.

Publicity. It soon became clear that the seven-week time frame and available resources were not sufficient to develop new public service material or billboards. St. Louis County and MoDOT members of the planning group formed an informal media planning committee and decided that the publicity program would begin with a press release several days prior to a kick-off event at a local hospital. They also decided that subsequent publicity to make the public aware of the enforcement activity would consist of a combination of variable message signs and permanent signs placed strategically along the targeted corridor. ${ }^{8}$

\footnotetext{
${ }^{7}$ In an enforcement zone, vehicles pass through an area where seat belt use among front-seat occupants is observed. Officers conduct a traffic stop if any occupants are unbuckled.

${ }^{8}$ Initial plans to provide usage rate feedback on some variable message boards were discarded due to a variety of obstacles such as the need for daily surveys to update the feedback signs and problems with using students to conduct such surveys.
} 


\section{Methodology and Results}

\section{A. Activity Levels}

\section{Media and Publicity}

A press release was issued on November 14, three days prior to the start of the enforcement activity and a media event was held on November 17, the first day of the enforcement effort. This event included the MoDOT Highway Safety Division director, the councilwoman who had introduced the primary enforcement ordinance and who was responsible for getting it implemented; the chief of the St. Louis County Police Department; the Emergency Medical Services director at St. Anthony's Hospital (the site of the event); a physician; and a local high school student. During the event, messaging focused on( a) the lifesaving benefit of seat belts; (b) the purpose of the county seat belt ordinance; (c) efforts to enact a statewide primary seat belt law; (d) the intensive enforcement activity that was about to begin; and (e) the number and locations of roadway signs being used to alert the public.

Roadway Signage. The final mix of roadway signs included six permanent signs and nine variable message boards. Three of the permanent signs were placed south of I-270, near the center of the targeted corridor, (see Map 2) and three were placed north of the intersection with I-270. Variable message boards were also placed on Highway 21 north and south of I-270, as well as on key collector roads.

All six permanent signs read "Buckle Up. It's the Law, County Ordinance 1217.095." Variable message boards contained a variety of messages including: "Buckle UpSeatbelt Law Enforced," "Click It or Ticket," and Buckle Up - It's the Law - Ordinance Enforced Ahead." The latter message was used on connectors approaching Highway 21.

Earned Media/News Stories. The press release and media event were intended to generate news storied in the local media. In addition, the SLCPD public information officer contacted local media outlets and provided them with information regarding the enforcement effort. Following the two-week effort, State and county officials reported a modest number of documented earned media (i.e., news stories) associated with the program. In addition to the kickoff event itself, 10 news stories covering the ongoing enforcement activity were reported on the Activity Report Form (Appendix A). Four stories were on local television, 3 on radio, and 3 in local newspapers.

\section{Enforcement}

Location, Timing, and Approach. The enforcement activity occurred on 11 of the 13 days from November 17 to November 29. On seven of these days, activity was limited primarily to daytime hours, usually from 7 a.m. to 7 p.m.. On four days, efforts continued through early and late nighttime hours, until 10 p.m. or midnight. In addition to conducting saturation patrols, all participating officers participating on a given day 
gathered at some time to conduct a highly visible enforcement zone, where one advance officer would observe seat belt violations and call them in to officers in chase vehicles further down the roadway.

Hours Expended and Citations Issued. Participating officers expended 502 hours of enforcement during the 13-day HVE effort, 318 (64\%) of which were part of regular patrols and $182(36 \%)$ of which were conducted as overtime activity. During these 502 hours, the six officers of the SLCPD Highway Safety Unit (plus a small group of officers assigned to the Affton Southwest Precinct of the SLCPD) saturated the corridor, actively looking for seat belt violations. ${ }^{9}$ These officers issued 991 citations and 140 warnings for seat belt violations, plus an additional 12 citations for child restraint violations. Thus, there were a total of 1,150 "actions" or "contacts" for occupant protection violations, $88 \%$ of which resulted in citations being issued.

Citation Rates and Benchmarks. Normally, an evaluation of an HVE program would include a calculation of the number of citations issued per 10,000 residents. However, because this was a corridor program that involved only a small segment of the county and because this was a commuter roadway, such a calculation was not considered to be appropriate. However, a simple comparison of the number of citations $(1,003)$ with the number of hours worked (500) provided a rate of approximately two citations per hour worked or, alternatively, about 30 minutes worked for each citation issued.

This rate is high, compared with the May 2008 CIOT average of 0.47 citations issued per hour worked $(637,211$ citations $\div 1,359,288$ hours worked $=0.47),{ }^{10}$ and compared with the benchmark provided by the 2005-06 Rural Demonstration Program (RDP) conducted in NHTSA's Region 5 (Nichols, Tison, Solomon, Ledingham, \& Preusser, 2009). The RDP produced a median citation rate of about 1.2 citations per hour (or 50 minutes of enforcement for each citation issued), compared with this corridor rate of 2 citations per hour (or 30 minutes per citation).

\footnotetext{
${ }^{9}$ Other officers assigned to patrolling beats along this route were also encouraged to make traffic stops, but these activities were not tracked.

${ }^{10}$ These data were derived from NHTSA's tracking system for May mobilization activity in the States (NHTSA, 2008c).
} 
Table 2. Enforcement Levels and Rates:

St. Louis County Versus Benchmarks

\begin{tabular}{|l|r|}
\hline \multicolumn{2}{|l|}{ SL. County HVE Program } \\
\hline Number of Hours Worked & 502 \\
\hline Number of Citations Issued & 1,003 \\
\hline Citations per Hour Worked & 2.0 \\
\hline \multicolumn{2}{|l|}{ 2008 Nationwide CIOT Mobilization } \\
\hline Number of Hours Worked & $1,359,288$ \\
\hline Number of Citations Issued & 637,211 \\
\hline Citations per Hour Worked & 0.47 \\
\hline 2005-06 Great Lakes RDP Program \\
\hline Median Citations per Hour & 1.2 \\
\hline Range & 0.1 to 4.1 \\
\hline Data for 2008 National CIOT mobilization from \\
NHTSA; data for 2005-06 Great Lakes RDP from \\
Nichols, Tison, Solomon, and Preusser (2009) \\
\hline
\end{tabular}

Other Enforcement Actions. In addition to citations and warnings issued for these violations of occupant protection laws, many additional enforcement actions resulted from this HVE effort. They included 6 arrests for driving while intoxicated, 3 felony arrests, 3 fugitives apprehended, 30 uninsured motorist violations, and 25 speeding violations.

\section{B. Public Awareness}

\section{Methodology}

With the help of the SLCPD, pre- and post-program motorist surveys were conducted at a single service station/convenience store located in the heart of the Highway 21 program corridor and at two service stations on the Highway 24 comparison corridor. At both the program and comparison sites, surveys were conducted during daylight hours, from 8 a.m. to 2 p.m. on Tuesday and from 1 p.m. to 6 p.m. on Wednesday. Surveys were conducted during the week prior to November 17 (baseline) and after November 30 (post-program) in both program and control areas. Although pre- and post-program surveys in program and control areas involved different samples of respondents, surveys were conducted as similarly as possible, using random selection of vehicles, times of day, days of week, and survey locations.

The survey procedure developed was as follows: Only drivers of randomly picked passenger vehicles approaching gas pumps would be asked to complete the survey. Once these drivers exited their vehicles and started pumping gas, they were approached by the surveyor who identified himself as conducting a research study for the county. The surveyor then asked drivers if they would participate in the research project by completing one-page surveys. Drivers were offered $\$ 2$ for their participation. If they agreed to participate, they were handed clipboards and pens to complete the survey (Appendix B). 
Prior to the baseline survey, there was a formative evaluation of survey procedures in the program area. During this 30-minute effort on Monday, November 10, approximately 30 brief interviews were conducted with motorists at the designated survey site to assess the feasibility of the survey approach and to estimate the volume of surveys that could be collected over a two-day period. No problems with the procedure were identified and the data from these 30 surveys were included in the baseline sample.

\section{Results}

Number of Respondents. A total of 1,597 drivers were surveyed; 810 drivers in the program area (401 during the week immediately prior to November 17 and 409 during the week immediately after November 30); and 787 drivers in the control area (390 and 397 in the pre- and post-program periods, respectively).

The pre- and post-program samples were compared with regard to age, gender, and vehicle type driven. In St. Louis County, there were no significant differences in the pre/post samples with regard to these characteristics. In Jackson County, the postprogram survey consisted of a larger percentage of younger respondents (ages 15 to 34), with $40 \%$ in the pre-program survey and $50 \%$ in the post-program survey $\left(X^{2}=7.61\right.$, $\mathrm{p}<0.01, \mathrm{df}=1)$. The two samples did not differ significantly in terms of gender or vehicle type.

Key Questions. Responses to several key questions were of greatest importance to this evaluation. They included:

a) Are you aware of recent seat belt enforcement efforts [on this roadway]?

b) How likely is it that you would get a ticket if you did not wear your seat belt in the next six months?

c) Would you favor a law that allows police to stop a vehicle whenever the driver is unbelted?

d) A multiple-choice question that asked about whether county or State police could enforce the law as a secondary law or as a primary law.

e) Another multiple-choice question asked about whether the seat belt law was enforced very strictly, somewhat strictly, not very strictly, rarely, or not at all.

Awareness of Seat Belt Enforcement Efforts. Awareness of seat belt enforcement on Highway 21 increased from 16.5\% (pre-program) to 77.0\% (post-program), a highly significant increase of 60.5 percentage points $\left(X^{2}=301.6, d f=1, p<0.0001\right)$. Results from the surveys in Jackson County showed a smaller, but significant, 9.3 point increase in perceived awareness of seat belt enforcement on Highway 24 (from $35.0 \%$ to $44.3 \%$ $\left(\mathrm{X}^{2}=7.095, \mathrm{df}=1, \mathrm{p}<0.01\right)$. The increase in St. Louis County was 6.5 times the increase in Jackson County (51.2 percentage points greater).

Perceived Risk of Getting a Ticket. The perceived risk of getting a ticket for riding unbuckled (for six months) increased from $21.6 \%$ to $32.4 \%$ in the program area, a highly significant increase of 10.8 percentage points $\left(\mathrm{X}^{2}=11.959, \mathrm{df}=1, \mathrm{p}<.001\right)$. There was a 
non-significant, 2.6 point decline (from $36.4 \%$ to $33.8 \%$ ) in Jackson County $\left(\mathrm{X}^{2}=0.566\right.$, $\mathrm{df}=1, \mathrm{p}>0.45)$. The difference in change between the program area increase and the control-area decline was 13.4 percentage points.

Favor a Primary Law. The percentage of respondents who favored a primary law increased significantly from $63.1 \%$ to $69.6 \%$ in St. Louis County, a 6.5 -point increase $\left(\mathrm{X}^{2}=3.914\right.$, $\mathrm{df}=1, \mathrm{p}<0.05)$. There was a non-significant decline, from $61.3 \%$ to $55.7 \%$ (-5.6 points) in Jackson County $\left(\mathrm{X}^{2}=2.569, \mathrm{df}=1, \mathrm{p}>0.10\right)$. The difference between program area increase and the control-area decline was 12.1 percentage points.

Perceive that County Police Can Enforce as a Primary Law. The percentage of respondents who thought that county police could enforce the seat belt law as a primary offense increased significantly from $61.5 \%$ to $69.4 \%$ in St. Louis County, a 7.9-point increase $\left(\mathrm{X}^{2}=5.65, \mathrm{df}=1, \mathrm{p}<0.05\right)$. No such increase was apparent in Jackson County, where about $50 \%$ of respondents, in both surveys thought that county police could use primary enforcement procedures. The difference between the program area increase and the control-area was 7.0 percentage points.

Although there was a slight increase in the proportion of St. Louis County respondents who thought that State Police could enforce the seat belt law as a primary law (from $65.7 \%$ to $70.4 \%)$, this shift was not statistically significant $\left(X^{2}=2.168, \mathrm{df}=1, \mathrm{p}>0.10\right)$. Here again, there was virtually no change among Jackson County respondents, $63 \%$ of whom thought that State police enforce the seat belt law using traditional (i.e., primary) enforcement procedures.

Table 2 and Figure 5 summarize the results of these four indices. In addition to the large and significant increase in perceived awareness of enforcement activity in St. Louis County, the consistency of pre-to-post trends is strongly indicative of the impact of the program on the Highway 21 corridor. Also important are the findings that (a) there was a significant increase in the proportion of St. Louis County respondents who thought that the seat belt law could be enforced as a primary law; and (b) there was an increase in support for primary law enforcement associated with the program. It is unclear why perceived risk of getting a ticket was higher in Jackson County than in St. Louis County but this perception declined (non-significantly) in Jackson County while it increased (significantly) in St. Louis County.

Perceived Strictness of Enforcement. Another question asked respondents to assess how strictly they thought that the police enforce the seat belt law: very strictly, somewhat strictly, not very strictly, rarely, and not at all. In St. Louis County, the proportion who said they thought the police enforced the law very strictly increased from $11.3 \%$ to $18.2 \%$, a significant increase of just under 7 percentage points $\left(X^{2}=7.59\right.$, df $\left.=1, p<0.01\right)$. In Jackson County there was a slight, non-significant decline, from $19.1 \%$ to $18.0 \%$, in the proportion of respondents who perceived strict enforcement of the seat belt law.

Table 2 summarizes the results for all six of the above indices. Figure 5 shows the results of the key indices in graphic form. 
Table 3. Results of Awareness Surveys in Program and Control Areas

\begin{tabular}{|c|c|c|c|c|c|c|}
\hline Index & County & $\begin{array}{c}\text { Pre } \\
\%\end{array}$ & $\begin{array}{c}\text { Post } \\
\%\end{array}$ & $\begin{array}{l}\text { Chg. } \\
\text { Pct. Pts. }\end{array}$ & $\mathbf{X}^{2}$ & p \\
\hline \multirow[t]{3}{*}{ Aware of SB Enforcement } & $\begin{array}{l}\text { St. Louis } \\
\mathrm{N}=\end{array}$ & $\begin{array}{r}16.5 \\
407\end{array}$ & $\begin{array}{r}77.0 \\
413\end{array}$ & 60.5 & 301.6 & $\begin{array}{c}<0.001 \\
* * *\end{array}$ \\
\hline & $\begin{array}{r}\text { Jackson } \\
\mathrm{N}=\end{array}$ & $\begin{array}{r}35.0 \\
394\end{array}$ & $\begin{array}{r}44.3 \\
395\end{array}$ & 9.3 & 7.095 & $\begin{array}{c}0.0077 \\
* *\end{array}$ \\
\hline & Program - Control & \multicolumn{5}{|c|}{51.2} \\
\hline \multirow[t]{3}{*}{ Perceive that Ticket is Likely } & $\begin{array}{l}\text { St. Louis } \\
\qquad \mathrm{N}=\end{array}$ & $\begin{array}{r}21.6 \\
407\end{array}$ & $\begin{array}{r}32.4 \\
411\end{array}$ & 10.8 & 11.959 & $\begin{array}{c}<0.001 \\
* * *\end{array}$ \\
\hline & $\begin{array}{r}\text { Jackson } \\
\mathrm{N}=\end{array}$ & $\begin{array}{r}36.4 \\
393\end{array}$ & $\begin{array}{r}33.8 \\
399\end{array}$ & -2.6 & 0.566 & 0.452 \\
\hline & Program - Control & \multicolumn{5}{|c|}{13.4} \\
\hline \multirow[t]{3}{*}{ Support Primary Enforcement } & $\begin{array}{l}\text { St. Louis } \\
\qquad \mathrm{N}=\end{array}$ & $\begin{array}{r}63.1 \\
406\end{array}$ & $\begin{array}{r}69.6 \\
408\end{array}$ & 6.5 & 3.914 & $\begin{array}{c}0.048 \\
*\end{array}$ \\
\hline & $\begin{array}{r}\text { Jackson } \\
\mathrm{N}=\end{array}$ & $\begin{array}{r}61.3 \\
388\end{array}$ & $\begin{array}{r}55.7 \\
388\end{array}$ & -5.6 & 2.569 & 0.109 \\
\hline & Program - Control & \multicolumn{5}{|c|}{12.1} \\
\hline \multirow[t]{3}{*}{$\begin{array}{l}\text { Perceive that County Police Can } \\
\text { Enforce as a Primary Law }\end{array}$} & $\begin{array}{l}\text { St. Louis } \\
\qquad \mathrm{N}=\end{array}$ & $\begin{array}{r}61.5 \\
408 \\
\end{array}$ & $\begin{array}{r}69.4 \\
415 \\
\end{array}$ & 7.9 & 5.650 & $\begin{array}{c}0.017 \\
*\end{array}$ \\
\hline & $\begin{array}{r}\text { Jackson } \\
\mathrm{N}=\end{array}$ & $\begin{array}{r}49.9 \\
395 \\
\end{array}$ & $\begin{array}{r}50.8 \\
400 \\
\end{array}$ & 0.9 & 0.061 & 0.805 \\
\hline & Program - Control $=$ & \multicolumn{5}{|c|}{7.0} \\
\hline \multirow[t]{3}{*}{$\begin{array}{r}\text { Perceive Strict Enforcement } \\
\text { Of Seat Belt Law }\end{array}$} & $\begin{array}{r}\text { St. Louis } \\
\mathrm{N}=\end{array}$ & $\begin{array}{r}11.3 \\
406 \\
\end{array}$ & $\begin{array}{r}18.2 \\
413 \\
\end{array}$ & 6.9 & 7.950 & $\begin{array}{c}0.006 \\
* *\end{array}$ \\
\hline & $\begin{array}{r}\text { Jackson } \\
\mathrm{N}=\end{array}$ & $\begin{array}{r}19.1 \\
393\end{array}$ & $\begin{array}{r}18.0 \\
400\end{array}$ & -1.1 & 0.154 & 0.695 \\
\hline & Program - Control $=$ & \multicolumn{5}{|c|}{8.0} \\
\hline
\end{tabular}

Figure 5. Results of Awareness Surveys in Program and Control Areas

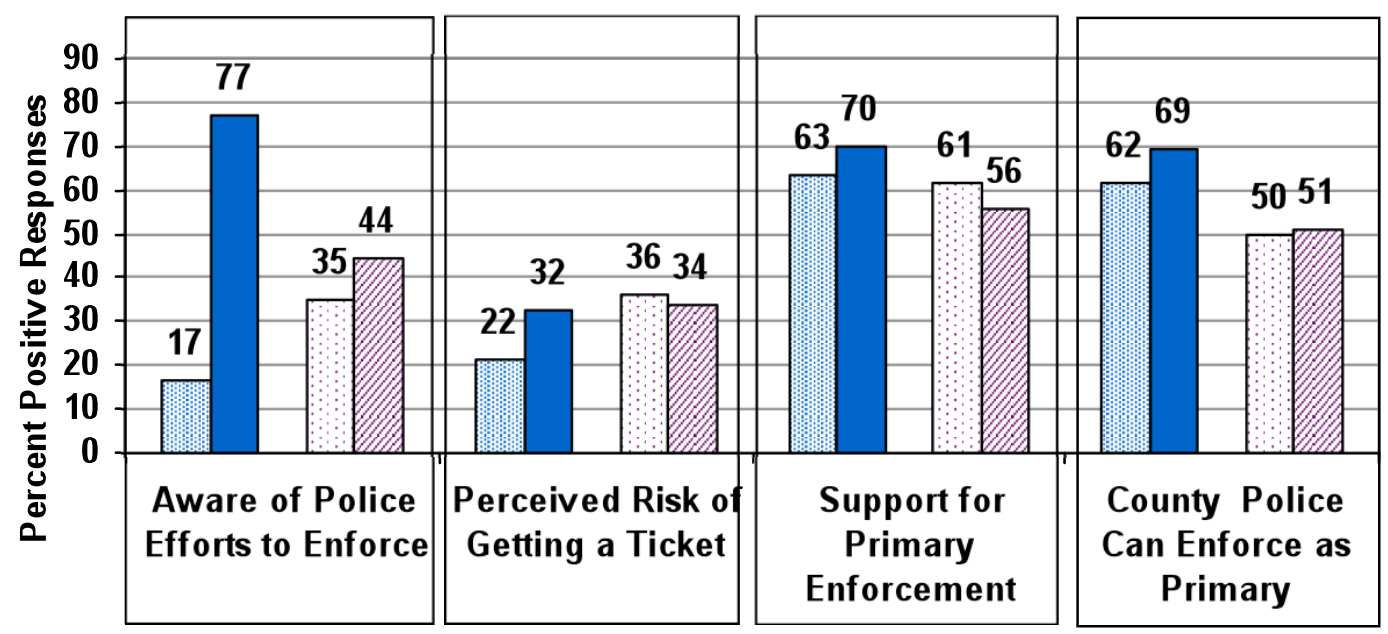

$\square$ Program (Pre) $\square$ Program (Post) $\square$ Control (Pre) $\square$ Control (post 


\title{
C. Observed Seat Belt Use
}

\author{
1. Methodology
}

Observations of seat belt use were conducted over four-day periods, from Monday through Thursday on both the Highway 21 and Highway 24 corridors. Each corridor was divided into segments. On Highway 21, these segments fell between Butler Road (southern boundary) and Reavis Road (northern boundary). On Highway 24, they fell between Blue Ridge Road (western boundary) and Bundshu Road (eastern boundary). Segments were identified as sections of roadway between two intersections or between designated landmarks. Within each segment, a location was identified where traffic could be easily and safely observed in both directions.

There were 15 time periods of observation for each survey wave (i.e., baseline and postprogram). These 15 time slots were randomly chosen from approximately 32 daylight hours between noon on Monday and noon on Thursday. Otherwise, potential hours of observation were from 7 a.m. through 4:45 p.m. ${ }^{11}$ The same time periods used for baseline surveys (November 10 through November 13) were repeated for post-program surveys (December 1 through December 4). The 15 minute observational period allowed time for travel and set up at the next location even when consecutive hours were chosen for observation.

For each time period, a roadway segment was randomly selected for observation and, at each observational site, both directions of travel were observed, using two observers equipped with clipboards and survey forms. When traffic was too heavy to observe all vehicles, a systematic procedure was used to select vehicles. Observers on each side of the road used "markers" (e.g., a driveway, sign, manhole cover, mailbox or some other visible object) to determine a "point of selection." After completing one observation, surveyors picked the next vehicle reaching the designated marker for observation.

\section{Results}

A total of 25,877 front-seat, passenger-vehicle occupants were observed in pre-program and post-program surveys (combined). About 48\% more observations were made in St. Louis County than in Jackson County, indicating a relatively higher volume of traffic in the program area than in the control area. Between 7,544 (baseline) and 7,910 (postprogram) observations were made in St. Louis County with only a very small percentage $(0.3 \%)$ resulting in undetermined usage. ${ }^{12}$

\footnotetext{
${ }^{11}$ In part for observer travel purposes, only afternoon hours were targeted for observations on Mondays (control area) and only morning hours were included for selection on Thursdays (program and control areas). In the program area, this procedure resulted in 1 time period selected on Monday afternoon; 4 on Tuesday; 5 on Wednesday; and 4 on Thursday. ${ }^{11}$ In the control area, it resulted in 3 observational periods on Monday afternoon; 5 on Tuesday; 5 on Wednesday; and 2 on Thursday.

${ }^{12}$ Three options were available with regard to consideration of unknowns: (a) include them in the denominator of the rate determination; (b) distribute them according to the ratio of cases where use is known; or (c) omit unknowns from the analysis, thus reducing the number of observations slightly. The last
} 
The pre- and post-program samples were very similar with regard to race, gender, and vehicle type driven. In St. Louis County there were no significant differences with regard to vehicle type or gender, although the pre-program sample had a higher percentage of Whites $(92 \%)$ than Non-Whites $(90 \%)$. This difference, although only 2 percentage points, was highly significant due to the large sample size $\left(X^{2}=14.69, \mathrm{p}<0.0001\right.$, $\mathrm{df}=1$ ). In Jackson County, the pre/post samples also did not differ with regard to vehicle type or gender but there were slightly more Hispanics (1\%) in the pre-program sample than in the post-program sample $(0 \%)$. This difference also was significant due to the large number of observations $\left(\mathrm{X}^{2}=23.74, \mathrm{p}<0.001, \mathrm{df}=1\right)$

The results of the mini-surveys conducted in St. Louis County showed a 4.9-percentagepoint increase in observed usage from $83.3 \%$ at baseline to $88.2 \%$, post-program $\left(\mathrm{X}^{2}=\right.$ $75.55, \mathrm{df}=1, \mathrm{p}<0.001)$. These are relatively high rates, compared with the $76 \%$ rate measured in 23 sites within the county in 2008 (see Figure 2). But, the baseline rate $(83.3 \%)$ is only modestly higher than the $80.5 \%$ rate measured at these sites in 2007 . Again, the baseline and post-program mini-surveys that were part of this study were conducted within one month of each other and under nearly identical circumstances (i.e., same days of week, time periods, observers, procedures, etc.). Thus, they likely represent a valid index of change, which is the most important characteristic from the standpoint of this evaluation.

\section{Table 4. Results of Observational Surveys in Program and Control Areas}

\begin{tabular}{|c|c|c|c|c|c|c|}
\hline Index & County & $\begin{array}{l}\text { Pre } \\
\%\end{array}$ & $\begin{array}{c}\text { Post } \\
\%\end{array}$ & $\begin{array}{c}\text { Chg. } \\
\text { Pct. Pts. }\end{array}$ & $\mathbf{X}^{2}$ & $\mathbf{p}$ \\
\hline \multirow[t]{3}{*}{ Drivers } & $\begin{array}{r}\text { St. Louis County } \\
\mathrm{N}=\end{array}$ & $\begin{array}{l}83.3 \\
6,425\end{array}$ & $\begin{array}{l}88.0 \\
6,851\end{array}$ & 4.7 & 60.28 & $<0.0001$ \\
\hline & $\begin{array}{r}\text { Jackson County } \\
\mathrm{N}=\end{array}$ & $\begin{array}{r}58.8 \\
4,796\end{array}$ & $\begin{array}{r}56.5 \\
2,247\end{array}$ & -2.3 & 4.679 & 0.0305 \\
\hline & Program - Control & \multicolumn{5}{|c|}{7.0} \\
\hline \multirow[t]{3}{*}{ Passengers } & $\begin{array}{l}\text { St. Louis County } \\
\mathrm{N}=\end{array}$ & $\begin{array}{l}83.5 \\
1.119\end{array}$ & $\begin{array}{l}89.4 \\
1.059\end{array}$ & 6.0 & 16.39 & $<0.0001$ \\
\hline & $\begin{array}{r}\text { Jackson County } \\
\mathrm{N}=\end{array}$ & $\begin{array}{r}48.3 \\
1,098\end{array}$ & $\begin{array}{r}45.0 \\
854\end{array}$ & -3.3 & 2.107 & 0.1466 \\
\hline & Program - Control & \multicolumn{5}{|c|}{9.3} \\
\hline \multirow[t]{3}{*}{ All Occupants } & $\begin{array}{l}\text { St. Louis County } \\
\mathrm{N}=\end{array}$ & $\begin{array}{r}83.3 \\
7,544\end{array}$ & $\begin{array}{r}88.2 \\
7,910\end{array}$ & 4.9 & 75.55 & $<0.0001$ \\
\hline & $\begin{array}{r}\text { Jackson County } \\
\mathrm{N}=\end{array}$ & $\begin{array}{r}56.9 \\
5,894\end{array}$ & $\begin{array}{r}54.6 \\
4,815\end{array}$ & -2.2 & 5.262 & 0.0217 \\
\hline & Program - Control & \multicolumn{5}{|c|}{7.1} \\
\hline
\end{tabular}

Usage increased most among passengers ( +6 points), reaching $89.4 \%$. Usage among drivers increased by 4.7 points, reaching $88 \%$. All increases in program areas were highly significant as indicated by chi-square tests $(\mathrm{p}<0.0001)$.

option was chosen for the very small number of unknowns in the data set. Thus, the Ns shown in the narrative and tables below are for observations that resulted in known use/non-use determinations. 
Figure 6. Results of Observational Surveys in Program and Control Areas

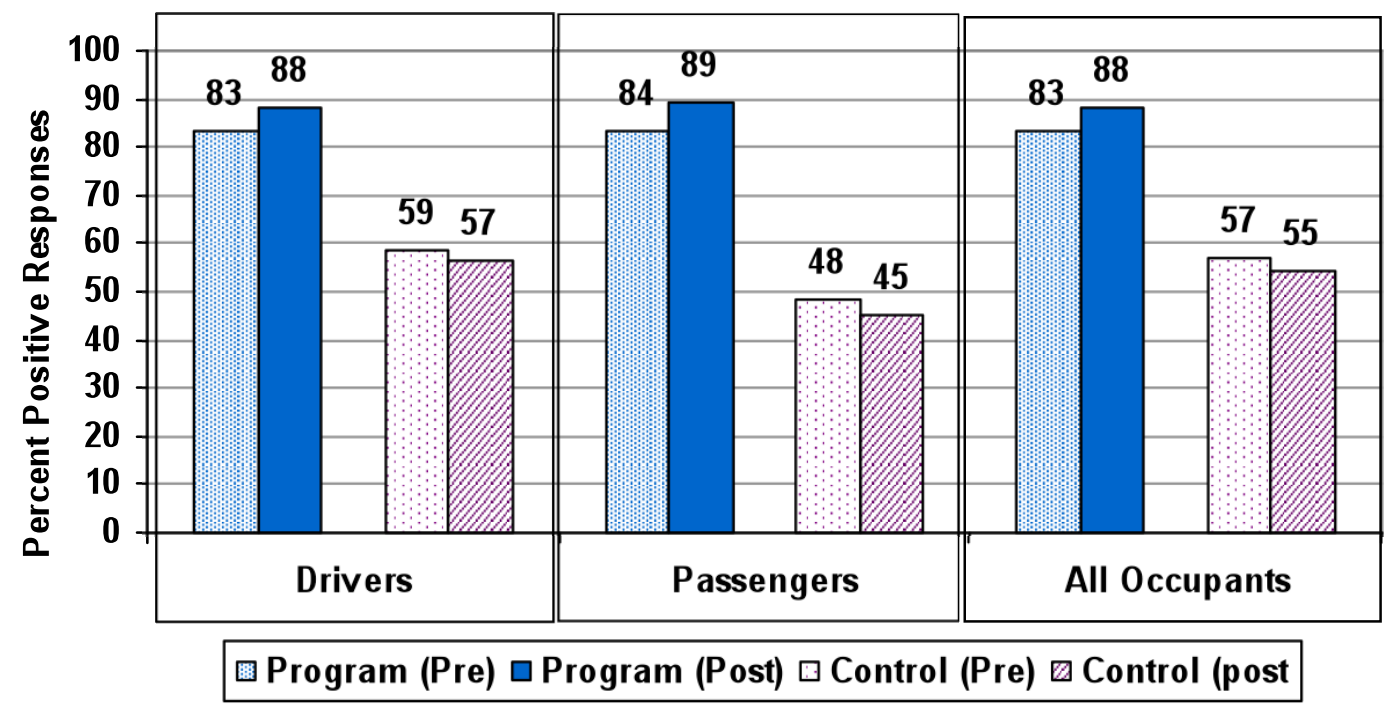

Overall usage declined (slightly but significantly) from baseline to the second survey in Jackson County. Further, observed usage was considerably lower in Jackson County than usage in St. Louis County. ${ }^{13}$ As Figure 4 suggested, usage was historically lower in Jackson County than in St. Louis County but only marginally so. Regardless of these differences in level of usage, this index certainly did not increase in the control area during the period of time when the HVE program was being implemented in the program area. Overall, the pre-to-post difference in change between these two areas was 7.1 percentage points (post program $_{-}$- pre program - ( post $_{\text {control }}$ - pre $\left._{\text {control }}\right)$.

\section{Officer Opinions and Perceptions}

There were three sources of officer opinions and perceptions. First, officers from the SLCPD Highway Safety Unit and several other officers that attended an October 16 meeting of the St. Louis Regional Traffic Safety Council were interviewed in two groups. This was approximately one month prior to the start of the HVE effort. Second, officers from the Highway Safety Unit were also surveyed approximately one month after the program was completed, using a brief one-page questionnaire. In addition, officer observations were included on the program Activity Report that was provided by the SLCPD after program completion.

\section{Pre-Program Interviews}

Based on pre-program information provided by officers in the Highway Safety Unit, they constituted a relatively experienced group, with 5-14 years spent as patrol officers and up to five years experience in the Highway Safety Unit. Each was highly motivated; each

\footnotetext{
${ }^{13}$ It is not totally clear why there was this difference in observed usage on these two corridors. It certainly was not expected, based on the data provided in the background section. However, some explanations were found that are described in the Discussion section of this report.
} 
strongly endorsed the need for seat belt use among police officers as well as among the public; and each endorsed the enforcement of seat belt laws. As a group, they pointed out that the passage of the county's primary ordinance was positively received in their Unit and that a similar ordinance had nearly been enacted in St. Louis City. They felt that the ordinance greatly facilitated their ability to issue tickets for seat belt violations.

These officers pointed out that, when the ordinance first went into effect, they were notified by the SLCPD Planning and Analysis Division and some publicity did accompany the implementation of the ordinance. Several members of the unit also said the low fine (\$10) limited its impact to some extent. Most officers were still writing seat belt tickets but most often along with citations for other violations.

In the second group, officers who were not from the Highway Safety Unit showed somewhat less enthusiasm for enforcing the seat belt law, although all of them wanted the statewide primary law to pass. They said such a law would provide "another tool in their chest" for increasing seat belt use. These officers also felt that the fine should be increased to a minimum of $\$ 25$.

\section{Post Program Officer Surveys}

After program completion, 7 officers, nearly all of which were members of the Highway Safety Unit, completed a simple one-page survey that asked about (a) how the enforcement effort went; (b) motorist reactions; (c) changes in their perceptions about the ordinance; (d) support for a statewide primary law; and (e) possible future activities to increase seat belt usage in the county (see Appendix D). Responses to these questions said all seven officers thought that the program had gone very well and that, as the HVE campaign continued, it became much harder to find violators.

With regard to motorist reactions, most officers stated that most motorists understood why they were enforcing the law and supported it but that there were some who thought that it was poor use of resources. One officer said most of the motorists ticketed did not even know that the county had a primary ordinance.

Every officer supported the county ordinance whole-heartedly and also thought that the State should enact a statewide primary law. Two said, after this effort, they were more aware of the ordinance and were enforcing it more frequently than before, particularly on its own merits and not as a secondary law. Several said they thought the fine should be increased from $\$ 10$ to a minimum of $\$ 25$.

With regard to how to increase usage or at least maintain a high rate in the county, these officers cited getting a statewide primary law, publicizing the law and their efforts, increasing the fine, and conducting additional enforcement campaigns.

Finally, with regard to the request for any additional comments regarding legislation or enforcement of a statewide law, six of the seven officers cited the need for a statewide primary law. 


\section{Comments from the Activity Report Form}

In addition to the informal focus groups and post-program surveys, the activity report form provided additional comments regarding the enforcement activity, officer impressions, and motorist responses. Following are the responses provided:

\section{a. General Comments}

- Checkpoints were not used due to the volume of traffic and because only two officers worked after dark;

- Enforcement after dark was extremely difficult; and

- Responses from businesses along the corridor were extremely positive for the increased officer visibility. One gas station reported that it had about $\$ 500$ in gas drive-offs the week before enforcement and no gas drive-offs during the two weeks of enforcement.

\section{$b$. Excuses Given by Motorists for Not Buckling Up}

Following are some of the excuses given by motorists during the enforcement activity:

I forgot; I'm close to where I'm going; I survived an accident BECAUSE I was NOT wearing a seat belt; It's uncomfortable (women mostly) (chest \& neck); I couldn't wear it because my dog is in my lap; I'm too fat; my (shirt pocket) pens get in the way; it rubs my neck; I'm pregnant and my doctor said not to wear it; I'm claustrophobic; and I have a hernia.

c. Other Comments and Observations

In addition to the above comments, the activity form listed the following observations:

- The majority of people who were wearing their seatbels) wrong most commonly had them under their left armpist, but two elderly adults (in the same car) had it wrapped around their necks.

- One person said, "I'll send you $\$ 100$ and you can write me 9 more [citations] later."

- No driver admitted to being stopped twice for not wearing a seat belt.

- Passengers typically didn't know that the law applied to them, too.

- Most teens didn't know that not wearing seat bels) was a violation of their restricted driver's licenses.

- The oldest person stopped that was not wearing a seatbelt and was 85 years old.

- One woman stopped for not wearing her seat belt was on her way to a support group for parents who lost their children in auto accidents and she admitted that she never wears her seatbelt due to it rubbing her neck. 


\section{E. Potential Impact of Statewide Primary Law}

The potential impact of a primary law upgrade, if Missouri was to enact one, was examined using three different scenarios: (1) assuming a 5-point increase as found in this corridor program; (2) assuming an 11-point increase, based on a recent review of primary laws; and (3) based on usage among occupants involved in potentially fatal crashes.

First, with a law upgrade and ongoing HVE efforts, it is reasonable to expect that Missouri would experience a 5-point increase in observed usage, similar to the gain associated with this corridor program. The problem with using an estimated 5-point gain is that, with a 2007 usage rate of only $77 \%$, Missouri would likely achieve a substantially greater increase in observed use associated with a law upgrade and continued HVE efforts. In neighboring Illinois, for example, usage increased from $74 \%$ in 2002 , the year prior to its law upgrade, to $90 \%$ in 2007. This represented a 16-point gain over the period of 6 years of mobilizations conducted in an upgraded law environment. More than half of that gain (9 percentage points) occurred in the 2 years from 2002 (the last full year prior to the upgrade) to 2004 (the first full year after the upgrade).

The second scenario assumed that Missouri would experience a larger (than 5-point) increase. For this scenario, we used an 11-point estimated gain in observed usage, based on a recent review by Nichols and Ledingham (2008). In this review, the average gain in observed usage associated with six upgrades implemented from 2000 through $2004 .{ }^{14}$ At the time, these were the most recent upgrades for which there was at least one post-law year of usage data.

The third approach examines potential impact based on changes in usage among occupants who are at highest risk of being involved in a serious crash (i.e., usage among occupants involved in potentially fatal crashes). This is a theoretical use rate that is based on the combination of usage among occupants killed in crashes and the estimated effectiveness of seat belts under various conditions (front seat/rear seat; cars/light trucks, etc.). This target group (people involved in potentially fatal crashes) is likely the most important group within which an increase in seat belt use can directly reduce fatalities. For this scenario, we relied on an estimated 10-point increase in potentially fatal crashes (and a 10.5-point increase in usage among occupants killed) associated with a primary law upgrade. This estimate was reported by Nichols and Ledingham and was based upon the experiences of the same six States that were used for estimating the impact of a primary law on observed usage. ${ }^{15}$

In order to arrive at our estimates of impact in terms of fatalities, injuries, and economic costs prevented, NHTSA's Belt Use program was used. This program is available from

\footnotetext{
${ }^{14}$ The upgrade States (along with year of upgrade and magnitude of impact) upon which this 11-point estimated gain is based were: New Jersey and Michigan $(2000 ;+15$ points and +12 points, respectively); Washington $(2002 ;+12$ points); Delaware and Illinois $(2003 ;+11$ points and +9 points, respectively); and Tennessee (2004; +5 points).

${ }^{15}$ These States (year of upgrade; and magnitude of change in UPFC) were as follows: New Jersey and Michigan $(2000 ;+5$ points and +7 points, respectively); Washington $(2002 ;+12$ points); Delaware and Illinois $(2003 ;+20$ points and +11 points, respectively); and Tennessee $(2004 ;+5$ points $)$.
} 
the agency's Motor Vehicle Safety (MVS) software located on its Web site. ${ }^{16}{ }^{17} \mathrm{We}$ provided the Belt Use program with the number of fatalities among occupants of passenger vehicles in Missouri for 2007 (758) and allowed the program to distribute these fatalities across the four relevant categories of fatality: front seat passenger car; rear seat passenger car; front seat, light truck or van (LTV); and rear seat LTV, according to a default distribution in the software that is based upon 2003 fatality data. We then estimated potential impact in terms of fatalities, injuries, and costs prevented for the three scenarios described above. ${ }^{18}$

Scenario \#1. For the first and most conservative scenario, we took the 2007 observed usage rate of $77 \%$ and assumed a 5-percentage-point increase to $81 \%$. We then used the 2007 number of passenger vehicle occupant fatalities (758) as a baseline. ${ }^{19}$ From this scenario, the Belt Use program provided an estimate of 32 fatalties and nearly 400 moderate to serious injuries prevented each year, producing an annual cost-savings of nearly $\$ 97$ million.

Scenario \#2. We then modeled the second scenario that assumed that an enforced law upgrade would result in an 11-point increase in observed usage. This scenario provided an estimate of 72 fatalities and 870 moderate-to-serious injuries prevented, for an annual cost savings of approximately $\$ 215$ million.

Scenario \#3. Using the approach based on changes in usage among crash victims (to estimated changes in usage among occupants involved in potentially fatal crashes), it was estimated that the upgrade, along with continued HVE efforts, would result in a 10percentage-point increase in usage among occupants killed in passenger vehicles. This scenario resulted in an estimated 53 fatalities and nearly 660 moderate-to-serious injuries prevented, for an annual cost savings of approximately $\$ 160$ million.

Thus, using these three different scenarios, the estimated number of fatalities that would be prevented each year ranged from over 30 to just over 70; the number of moderate-toserious injuries that would be prevented ranged from about 400 to nearly 900; and the resulting cost-savings ranged from just under $\$ 100$ million annually to approximately \$215 million.

\footnotetext{
${ }^{16}$ One can search on "MVS" at www.nhtsa.dot.gov; the MVS software must then be downloaded and installed.

${ }^{17}$ This software is based upon a series of comprehensive reports regarding the economic costs of motor vehicle crashes (Blincoe \& Faigin, 1992; Blincoe, 1996; and Blincoe, Seay, Zaloshnja, Miller, Romano, Luchter, \& Spicer, 2002).

${ }^{18}$ All economic data were adjusted from 2003 dollars to 2008 dollars, using a factor of 1.15. This factor was obtained from the inflation calculator found at the Bureau of Labor Statistics Web site, www.bls.gov.

${ }^{19}$ The reason for using these numbers is that 2007 is the most recent year for which both observed use and number of occupant fatalities is available at this writing.
} 


\section{Discussion}

The Program. This corridor program was developed and implemented to evaluate the potential impact of an intensive HVE program, in combination with a primary enforcement ordinance, within a secondary law State unable to increase usage over the past several years. It was characterized by a strong enforcement effort, with approximately two citations issued per officer hour worked. This rate compares with 1.2 citations per hour worked in the recent Great Lakes Rural Demonstration program (Nichols, Tison, Solomon, \& Preusser, 2009) and about one citation for every two hours worked in the May 2008 National CIOT (based on data provided in NHTSA, 2008c). However, it also was characterized by an absence of paid media and little or no broadcast media other than news stories. Publicity for the enforcement effort was generated by a combination of a news release, a single media event, a combination of permanent and variable message road signs, and the enforcement activity itself (which included a daily enforcement zone) within the area covered by the primary seat belt ordinance.

Impact on Awareness and Perceptions. The results show a significant increase in all indices of public awareness and perception, such as awareness of special enforcement efforts ( +60.5 percentage points); perception that a ticket is likely for not buckling up $(+10.8$ points); perceived authority for the county police to enforce the seat belt law as a primary offense ( +7.9 points); perception of very strict enforcement ( +6.9 points); and support for primary enforcement ( +6.5 points). ${ }^{20}$ The magnitude of these changes is considerably greater than the magnitude of statewide changes associated with the recent Buckle Up in Your Truck demonstration program implemented in 2006 and 2007. In that program, for example, awareness of special enforcement efforts increased by an average of about 24 percentage points and perception that a ticket is likely for not buckling up increased by an average of 2 to 3 percentage points.

Motorist Support for a Primary Law. That motorist support for a primary law increased in conjunction with the enforcement campaign is worth noting. This result provided one more piece of evidence to a very consistent body of research that shows that public support for primary enforcement is higher in primary law States than in secondary law States. Further, it is consistent that such support generally increases when a primary law is enacted and/or when such a law is enforced.

One question posed by the results is why perceived risk of receiving a ticket was higher in Jackson County than in St. Louis County. The answer to this question is not immediately apparent. However, it should be noted that these results emanate from one or two site awareness surveys that were conducted using the same procedures at baseline and post-program. As such, they should be viewed as indices of change, rather than as representative estimates of awareness levels that can be compared with each other. It is certainly possible that, if more sites were surveyed or if different sites were surveyed, the levels would be different. Because of the consistency of procedure, however, the changes in these levels (i.e., from baseline to post-program) can be compared from one corridor to

\footnotetext{
${ }^{20}$ These gains represent only the changes in the program area. In comparison with changes in the control corridor, such gains were nearly always even larger.
} 
another. Further, the magnitude and the consistency of the results add considerable confidence to the conclusion that they were associated with the implementation of the HVE program.

Impact on Observed Usage. With regard to the primary objective of increasing seat belt usage, this HVE program was associated with a significant increase in observed usage in the targeted corridor ( +4.7 points), while usage in the control corridor declined slightly. Considering both trends, there was a 7.1-percentage-point impact (post program - pre program) (post control $_{\text {- pre }}$ control). Since the individual effects were statistically significant and in opposite directions, we can say with confidence that usage in the program area improved significantly more than in the control area. Further, the inclusion of a control corridor strengthens the evidence that the increase in usage observed on the Highway 21 corridor was associated with the HVE program.

Usage Among Occupants of Pickup Trucks. There were significant increases among pickup truck occupants as well as among occupants of other vehicles. In fact, increases in usage in pickup trucks were approximately the same as in other vehicles. This is important in that occupants of pickup trucks have historically had lower observed usage than occupants of other vehicles in Missouri, as well as in most other States. These differences appear to be smaller in primary law States, such as in neighboring Iowa, than in secondary law States and they frequently diminish when a primary law is enacted and enforced, such as in Michigan (Eby, Vivoda, \& Fordyce, 2002) and in Illinois (Nassirpour, 2004a; 2004b; 2005; 2006; 2007; 2008). The Illinois data are particularly compelling in that this is a neighboring State where the increase in usage among occupants of pickup trucks has increased by 1.4 times the increase among passenger cars, since Illinois enacted its primary law upgrade in 2003 and participated in annual mobilizations.

Another question arises with regard to why the baseline usage rate in St. Louis County $(83.3 \%)$ was so high, compared with the historical rates derived from the 23 county sites that are part of the annual statewide survey (74.7\%). Figure 4 shows these historical rates and, while a similarly high rate $(82.3 \%)$ was recorded for 2005 , there was evidence of a decline in recent years. Site \#14 from the statewide survey is the only site in the county that is located on the targeted corridor and it also showed a rate of only $77 \%$ in 2008. There is no clear answer to why the mini-surveys conducted as part of this program (baseline and post-program) were higher than these other indices. However, these 15-site mini-surveys were likely the most complete and representative measures of usage on the Highway 21 corridor as they sampled the entire length of the corridor. All other indices (i.e., the 23-site county sample and the Site \#14 data) included within it constituted only one site situated on this roadway. Since the surveys were conducted using consistent procedures from baseline to post-program, they represent valid indices of change in both the program and control areas.

There is a third question of why usage rate along Highway 21 in St. Louis County (83.3\% at baseline) was approximately 1.5 times as high as usage along Highway 24 in Jackson County (57\% at baseline). While past observational data said St. Louis County 
historically had higher usage than Jackson County, this gap appeared to be decreasing in recent years. Here, there is some additional corroboration of a lower usage rate in this control corridor. An examination of FARS data for 2007, the last year for which such data are available, also found usage among fatalities in St. Louis County (37.5\%) to be about 1.6 times the rate in Jackson County (23.7\%), similar to the ratio derived from the 15 -site, mini-observational surveys.

Officer Support for a Primary Law. The comments of participating officers showed unanimous support for St. Louis County's primary enforcement ordinance and these officers were even more supportive of a statewide primary law. The most consistently offered response in post-program officer surveys was that a statewide primary law would be the most effective way to maintain a high usage rate across the State.

Potential Impact of a Statewide Primary Law: Different Scenarios. In summary, the 5percentage-point gain measured in this corridor project occurred from a reasonably high baseline rate and in the absence of any broadcast media. These findings suggest that there is substantial potential for gain in other jurisdictions that may wish to enact and enforce a primary enforcement ordinance.

Missouri is already participating in annual HVE mobilizations. If that continues, the results of this study and the experiences of other upgrade States suggest that Missouri would enjoy a significant statewide increase in usage. No one can say exactly how large such an increase might be but it would likely be somewhere between 5 and 11 percentage points in terms of observed usage, usage among crash victims, and usage among occupants involved in potentially fatal crashes - the most important target group. If Missouri realized a 5 percentage point increase in belt use, the State could expect to save 32 lives, prevent 400 injuries, and save nearly $\$ 97$ million per year. With an 11-point increase the savings climb to 72 lives, 870 injuries, and \$215 million. Lastly, if belt use among those involved in potentially fatal crashes rose 10 percentage points as many as 70 lives, 900 injuries, and as much as $\$ 215$ million could be saved. A mid-point estimate suggests that the combination of law upgrade and continued (possibly intensified) HVE efforts would result in the prevention of about 50 fatalities and 600 moderate-to-serious injuries annually, for a cost savings of about $\$ 160$ million.

Limitations. The above scenarios are, of course, hypothetical in that the program was implemented in only one unincorporated area of St. Louis County and not across all of the unincorporated areas of the county, much less the entire county or the entire State. With regard to the program area, however, there was a substantial number of observational sites (15) distributed across the 8-mile corridor and these sites were randomly distributed across all potential daylight time periods. Further, comparisons of vehicle type, gender, race, and ethnicity indicated that the pre- and post-program observational survey samples were remarkably similar. 


\section{References}

Blincoe, L. J. (1996). The economic cost of motor vehicle crashes, 1994. DOT HS 808 425. Washington, DC: National Highway Traffic Safety Administration.

Blincoe, L., Seay, A., Zaloshnja, E., Miller, T., Romano, E., Luchter, S., \& Spicer, R. (2002). The economic impact of motor vehicle crashes, 2000. DOT HS 809446.

Washington, DC: National Highway Traffic Safety Administration.

Blincoe, L. J. \& Faigin, B. M. (1992). The economic cost of motor vehicle crashes, 1990. DOT HS 807 876. Washington, DC: National Highway Traffic Safety Administration.

Eby, R. W., Vivoda, J. M., \& Fordyce, T. A. (2002). The effects of standard enforcement on Michigan safety belt use. Accident Analysis and Prevention 34:815-823.

Kahane, C. J. (2004). Lives Saved by Federal Motor Vehicle Safety Standards and Other Vehicle Safety Technologies, 1960-2002 - Passenger Cars and Light Trucks - With a Review of 19 FMVSS and Their Effectiveness in Reducing Fatalities, Injuries, and Crashes. Report DOT HS 809 833. Washington DC: National Highway Traffic Safety Administration.

Kahane, C. J. (2000). Fatality Reduction by Safety Belts for Front-Seat Occupants of Cars and Light Trucks. DOT HS 801 988. Washington DC: National Highway Traffic Safety Administration.

Ledingham, K. A., Tison, J., Casanova, T., \& Preusser, D. P. (under review). Increasing Seat Belt use in New York City: Evaluation of a Demonstration Project. Contract DTNH22-05-D-15043. Washington, DC: National Highway Traffic Safety Administration.

Nassirpour, M. (2001). Safety Belt Usage in Illinois: November 2001 Observational Survey Results. Springfield, IL: Illinois Department of Transportation, Division of Traffic Safety.

Nassirpour, M. (2002). Safety Belt Usage in Illinois: June 2002 Observational Survey Results. Springfield, IL: Illinois Department of Transportation, Division of Traffic Safety.

Nassirpour, M. (2004a). Safety Belt Usage in Illinois: December 2003 Observational Survey Results. Springfield, IL: Illinois Department of Transportation, Division of Traffic Safety.

Nassirpour, M. (2004b). Safety Belt Usage in Illinois: June 2004 Observational Survey Results. Springfield, IL: Illinois Department of Transportation, Division of Traffic Safety.

Nassirpour, M. (2005). Safety Belt Usage in Illinois: June 2005 Observational Survey Results. Springfield, IL: Illinois Department of Transportation, Division of Traffic Safety. 
Nassirpour, M. (2006). Safety Belt Usage in Illinois: June 2006 Observational Survey Results. Springfield, IL: Illinois Department of Transportation, Division of Traffic Safety.

Nassirpour, M. (2007). Safety Belt Usage in Illinois: June 2007 Observational Survey Results. Springfield, IL: Illinois Department of Transportation, Division of Traffic Safety.

Nassirpour, M. (2008). Safety Belt Usage in Illinois: June 2008 Observational Survey Results. Springfield, IL: Illinois Department of Transportation, Division of Traffic Safety.

NHTSA. (2008a). Seat belt use in 2008 - overall results. Traffic Safety Facts: Research Note. DOT HS 811 036. Washington DC: National Highway Traffic Safety Administration.

NHTSA. (2008b). Seat belt use in 2007 - use rates in the states and territories. Traffic Safety Facts: Crash-Stats. DOT HS 810 949. Washington DC: National Highway Traffic Safety Administration.

NHTSA. (2008c). Regional and State Reports on Data Submitted During NHTSA May 2008 Click It or Ticket. Washington, DC: National Highway Traffic Safety Administration.

NHTSA. (2007). Seat belt use in 2006 - use rates in the States and Territories. Traffic Safety Facts: Crash-Stats. DOT HS 810 690, Washington DC: National Highway Traffic Safety Administration.

NHTSA. (2005). Seat belt use in 2005 - use rates in the States and Territories. Traffic Safety Facts: Research Note. DOT HS 809 970, Washington DC: National Highway Traffic Safety Administration.

Nichols, J. L., \& Jones, R. K. (under review). Increasing Safety Belt Usage in the United States: A Review of the State of Knowledge. Volume I. Safety Belt Legislation. Washington, DC: National Highway Traffic Safety Administration.

Nichols, J. L., Tison, M. G., Solomon, K. A., Ledingham, K. A., Preusser, D. F., \& Siegler, J. N. (2009, June). Evaluation of Buckle Up in Your Truck)Programs. DOT HS 811 131. Washington, DC: National Highway Traffic Safety Administration.

Nichols, J. L., \& Ledingham, K. A. (2008).The impact of legislation, enforcement, and sanctions on safety belt use. NCHRP Report 601. Washington, DC. National Cooperative Highway Research Program. Transportation Research Board.

Nichols, J. L., Tison, J., Solomon, M. G., Ledingham, K. A., \& Preusser, D. F. (2009). Evaluation of a Rural Demonstration Program (RDP) to Increase Seat Belt Use in the Great Lakes Region. DOT HS 811 084. Washington, DC: National Highway Traffic Safety Administration. 
Nichols, J. L., Ledingham, K. A., \& Preusser, D. F. (2007). Effectiveness of the May 2005 Rural Demonstration Program and the Click It or Ticket Mobilization in the Great Lakes Region: First Year Results. Final Report. DOT HS 810 753. Washington, DC: National Highway Traffic Safety Administration. 


\section{Appendix A. Activity Reporting Form - (Completed)}

Number of Citations Issued for Seat Belt Violations - 991

Number of Citations Issued for Child Passenger Safety Violations - 12

Number of Warnings Issued for Seat Belt Violations - 140

Number of Warnings Issued for Child Passenger Safety Violations - 0

Agencies that Enforced on the Highway 21 Corridor - 1

Approximate Total Number of Hours Spent on Seat Belt Enforcement - 502.5

Approximate Number of Overtime Hours - 182.5

Approach(es) Used:

Checkpoints - No; If Yes, approximate number conducted

Enforcement Zones - Yes; If Yes, approximate number conducted - 10

Saturation Patrols - Yes; If Yes, approximate frequency used - DAILY

Regular Traffic Enforcement - No;

In your own words, please describe the enforcement effort, including reference to the approaches outlined above.

Beginning 11/17/08 and ending on 11/30/08, the Highway Safety Unit saturated Highway 21 between Highway 30 and the County Line. A small group of officers assigned to the Affton Southwest Precinct also participated in enforcement for 80 of the 182.5 overtime hours. Officers assigned to patrolling beats along the route were encouraged to make traffic stops, but these were not tracked. At certain times each day, all officers participating in the enforcement were gathered together into an enforcement zone where one officer would observe violations and call them out to chase cars. Enforcement occurred on the following dates and times:

$11 / 17$ - 7am to $7 \mathrm{pm} ; 11 / 18$ - 7 am to $7 \mathrm{pm} ; 11 / 19$ - 7 am to $12 \mathrm{am} ; 11 / 20$ - 7 am to $12 \mathrm{am} ; 11 / 21$ - $2 \mathrm{pm}$ to $10 \mathrm{pm} ; 11 / 22$ - 10am to $1 \mathrm{pm}, 11 / 24$ - 7 am to $7 \mathrm{pm} ; 11 / 25$ - 7 am to $7 \mathrm{pm} ; 11 / 26$ - 8am to $12 \mathrm{am} ; 11 / 28$ - 9am to $5 \mathrm{pm} ; 11 / 29$ - 9am to $6 \mathrm{pm}$

Although not essential, it may be useful (for you as well to respond to media) to know how many additional actions were taken during this seat belt enforcement effort. If possible, please provide the number of actions taken for the following offenses:

DWI arrests - 6 Felony Arrests - 3 Stolen Vehicles Recovered - 0

Fugitives Apprehended - 3 Uninsured Motorists - 30 Speeding Violations - 25

Reckless Driving - 0 Drug-Related Arrests - 0 Other (specify): Traffic Stops - 1,149

Any Other Comments Regarding Enforcement Activity (obstacles, comments, etc.)

Enforcement after dark was extremely difficult. Checkpoints were not utilized due to the volume of traffic and only two officers worked after dark. No driver admitted to being stopped twice for not wearing his or her seat belt. Responses from businesses along the corridor were extremely positive for the increased officer visibility. One gas station reported that they had about $\$ 500$ in gas drive-offs the week before enforcement and no gas drive-offs during the two weeks of enforcement. 
Common or strange excuses: -I forgot. -I'm close to where I'm going. -I survived an accident BECAUSE I was NOT wearing a seat belt. -It's uncomfortable (women mostly) (chest \& neck). -Couldn't wear it because my dog is in my lap. -I'm too fat. -My pens get in the way (shirt pocket pens). -Rubs my neck. -I'm pregnant and my doctor said not to wear it. -I'm claustrophobic. -I have a hernia.

Observations: Majority of people who were wearing it wrong most commonly had it under their left armpit, but 2 elderly adults in same car had it wrapped around their neck. One person said, "I'll send you $\$ 100$ and you can write me 9 more later." Passengers typically didn't know that the law applied to them too. Most teens didn't know that not wearing it was a violation of their restricted driver's license. Oldest person stopped that was not wearing it was 85 yrs. old. One woman stopped for not wearing hers was on her way to a support group for parents who lost their children in auto accidents and admitted she never wears it due to it rubbing her neck.

\section{Media Activity Reporting}

How many variable message roadway signs were used? - 9

What messages were displayed? (e.g. "Seat Belt Law Enforced"” Click It or Ticket" etc.)

Buckle Up - Seatbelt Law Enforced: frequency (e.g. daily) - Daily on signs on Hwy 21

Buckle Up - It's the Law - Ordinance Enforced Ahead: frequency - Daily on connectors, Reavis Rd, Green Park Rd, Mattis Rd, Kennerly and Butler Hill, as you approach Hwy 21

How many other roadway signs were used? (Please describe, including number)

Six permanent signs installed that read "Buckle Up, It's the Law, County Ordinance 1217.095"

Please describe any other outdoor or roadway publicity (e.g. posters, none, etc.) - None

Media Events. Please describe any media events conducted during the 14-day period (include location(s), speakers, media attendance, etc.

A kick-off event was held on 11/17/08 on the parking lot of St. Anthony's Hospital, speakers were Councilwoman Barbara Frasier (who introduced the primary ordinance), Chief Jerry Lee, two doctors (one who had lost her son in an accident), one teen who had survived an accident, and Leanna Depue, Director of the MO Highway Safety Division. Three television stations, two newspapers and radio outlets attended.

News Stories. Television; Approximate Number of stories - 4

Radio; Approximate Number of stories - 3

Newspaper; Number of stories - 3

Did you use any of the NHTSA media materials (OpEd pieces, letters to editor, etc.)?

We distributed brochures on traffic stops. 


\section{Appendix B. Motorist Awareness Survey Form}

Thank you for agreeing to complete this survey. All responses are voluntary and anonymous

1. Your sex:

Male $\quad \square$ Female

2. Your age:

$\square$ 15-17 $\square$ 18-24 $\square$ 25-34 $\square$ 35-44 $\square$ 45-54 $\square$ 55-64 $\square 65$ or older

3. What type of vehicle do you drive most often?

$\square$ Car $\quad \square$ Pickup $\quad \square$ SUV $\square$ Mini-Van $\quad \square$ Large Van $\square$ Other

4. Do you think the Police enforce the seat belt law:

$\square$ Very strictly $\quad \square$ Somewhat strictly $\quad \square$ Not very strictly $\quad \square$ Rarely $\quad \square$ Not at all

5. How likely is it that you would get a ticket if you didn't wear your seat belt in the next six months?

$\square$ Certain $\quad \square$ Very Likely $\quad \square$ Somewhat Likely $\quad \square$ Unlikely o Very Unlikely

6. In the past 30 days, how often have you driven on U.S. 21 [24]?

$\square$ Every day $\quad \square$ Several times a week $\quad \square$ Two or three times

7. Are you aware of recent seat belt enforcement efforts specifically on U.S. 21 [24]?

Yes $\square$ No

8. If someone is driving unbelted, which of the following is true (Check all that apply):

State Police can give a seat belt ticket only if they stop the vehicle for something else

State Police can give a seat belt ticket whenever they see the driver not wearing a belt

County Police can give a seat belt ticket only if they stop the vehicle for something else

County Police can give a seat belt ticket whenever they see the driver not wearing a belt

9. Would you favor a law that allows Police to stop a vehicle whenever the driver is unbelted?

$\square$ Yes $\quad \square$ No 


\section{Appendix C: Missouri Seat Belt Observation Form}

SITE NUMBER:

SITE:

NOTES

CONDITIONS

DATE: - - -

DIRECTION OF TRAFFIC FLOW (Circle one): N S E W Raining (Observation period will last exactly 45 minutes)

START TIME:

\section{DRIVER}

\begin{tabular}{|c|c|c|c|c|c|c|c|}
\hline \multicolumn{3}{|c|}{ VEHICLE } & \multicolumn{2}{|c|}{ DRIVER } & \multicolumn{3}{|c|}{ PASSENGER } \\
\hline Veh. & $\begin{array}{l}\text { Vehicle } \\
C=\text { car } \\
T=\text { truck }\end{array}$ & $\begin{array}{l}\text { Race } \\
W=\text { White } \\
B=\text { Black } \\
H=\end{array}$ & $\begin{array}{l}\text { Sex } \\
M=\text { male } \\
F=\text { female }\end{array}$ & $\begin{array}{l}\text { Use } \\
Y=\text { yes } \\
\mathrm{N}=\text { no }\end{array}$ & $\begin{array}{l}\text { Race } \\
\text { W = White } \\
B=\text { Black } \\
\mathrm{H}=\end{array}$ & $\begin{array}{l}\text { Sex } \\
M=\text { male } \\
F=\text { female }\end{array}$ & $\begin{array}{l}\text { Use } \\
Y=\text { yes } \\
N=\text { no }\end{array}$ \\
\hline 1 & & & & & & & \\
\hline 2 & & & & & & & \\
\hline 3 & & & & & & & \\
\hline 4 & & & & & & & \\
\hline 5 & & & & & & & \\
\hline 6 & & & & & & & \\
\hline 7 & & & & & & & \\
\hline 8 & & & & & & & \\
\hline 9 & & & & & & & \\
\hline 10 & & & & & & & \\
\hline 11 & & & & & & & \\
\hline 12 & & & & & & & \\
\hline 13 & & & & & & & \\
\hline 14 & & & & & & & \\
\hline 15 & & & & & & & \\
\hline 16 & & & & & & & \\
\hline 17 & & & & & & & \\
\hline 18 & & & & & & & \\
\hline 19 & & & & & & & \\
\hline 20 & & & & & & & \\
\hline
\end{tabular}




\section{Appendix D: Post- Program Survey for Participating Police Officers}

1) In your own words, how did the two-week enforcement period go? (positives and negatives).

2) Since the two-week enforcement period, has your opinion of the ordinance changed in any way? If so, please explain.

3) Do you think a statewide primary law would result in more seat belt enforcement by other departments? Yes No (Circle One). If yes, please briefly explain why.

4) How do you feel about future activities to increase seat belt use in St. Louis County? What is the best way to increase or maintain usage at a high level? 

DOT HS 811292

May 2010 